\title{
ANNUAL REPORT ON MONITORING OF THE UNSATURATED ZONE AND RECHARGE AREAS AT INEL
}

to the

State of Idaho INEL Oversight Committee

DOE/ID/13042--18

DE93 012946

prepared by

Idaho Water Resources Research Institute

University of Idaho

Moscow, Idaho

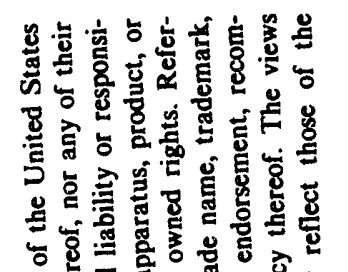

Bradley King

Department of Agricultural Engineering

George Bloomsburg

Department of Agricultural Engineering
Dennis Horn
Department of Civil Engineering
Jim Liou
Department of Civil Engineering
John Finnie
Department of Civil Engineering

\section{MASTER}




\section{INTRODUCTION}

The Idaho National Engineering Laboratory (INEL) is operated by the U.S. Department of Energy primarily to build, operate, and test nuclear reactors. In addition, the INEL supports other government-sponsored projects such as energy, defense, environmental, and ecological research.

The INEL covers about $890 \mathrm{mi}^{2}$ of the eastern Snake River Plain in southeastern Idaho (Fig. 1). The plain is a structural and topographic basin about $200 \mathrm{mi}$ long and 50 to $70 \mathrm{mi}$ wide. Thickness of surficial sediment deposits at the INEL ranges from 0 to $345 \mathrm{ft}$. Thin basaltic lava flows, rhyolitic rocks, and interbedded sedimentary deposits underlie the plain to depths of 2,000 to $10,000 \mathrm{ft}$. Basaltic rocks and interbedded sedimentary deposits in the upper 1,000 to 2,000 ft combine to form the Snake River Plain aquifer--a major source of water in southeastern Idaho; the INEL obtains its entire water supply from the aquifer. Aqueous chemical and radioactive wastes have been discharged to deep wells and shallow ponds at the INEL since 1952 and have affected the quality of the groundwater in the underlying Snake River Plain aquifer. Many of these waste constituents entered the aquifer either directly through disposal wells or indirectly following percolation from the ponds through the unsaturated zone.

\section{REGIONAL HYDROLOGY}

The eastern Snake River Plain is underiain by the Snake River Plain aquifer, a vast ground-water reservoir that may contain more than 1 billion acre- $\mathrm{ft}$ of water (Barraclough et al, 1981). The flow of ground water in the aquifer is chiefly to the south-southwest (Fig. 1) at velocities of 5 to $20 \mathrm{ft} / \mathrm{d}$ (Robertson et al, 1974). The transmissivity of the aquifer generally ranges from 134,000 to $13,400,000$ $\mathrm{ft}^{2} /$ day (Robertson et al, 1974).

Basaltic lava flows and interbedded sedimentary deposits are the main rock units that make up the aquifer. Water is contained in and moves through intercrystalline and intergranular pores, fractures, cavities, interstitial voids, interflow zones, and lava tubes. Openings in the rock units and their degree of interconnection complicate the movement of groundwater in the aquifer.

Groundwater inflow to the aquifer at the INEL consists mainly of underflow from the northeastern part of the plain and from drainages on the west and north. Most of the groundwater is recharged in the uplands to the northeast, moves southwestward through the aquifer, and is discharged to springs along the Snake River near Hagerman (Fig. 1). Lesser amounts of water are derived from local precipitation on the plain. Part of the precinitarion evaporates but part infiltrates the ground surface and percolates dcwnward to the aquifer. Ai the INEL, signinivant recisarge is derived from intermittent flows in the Big Lost River. 


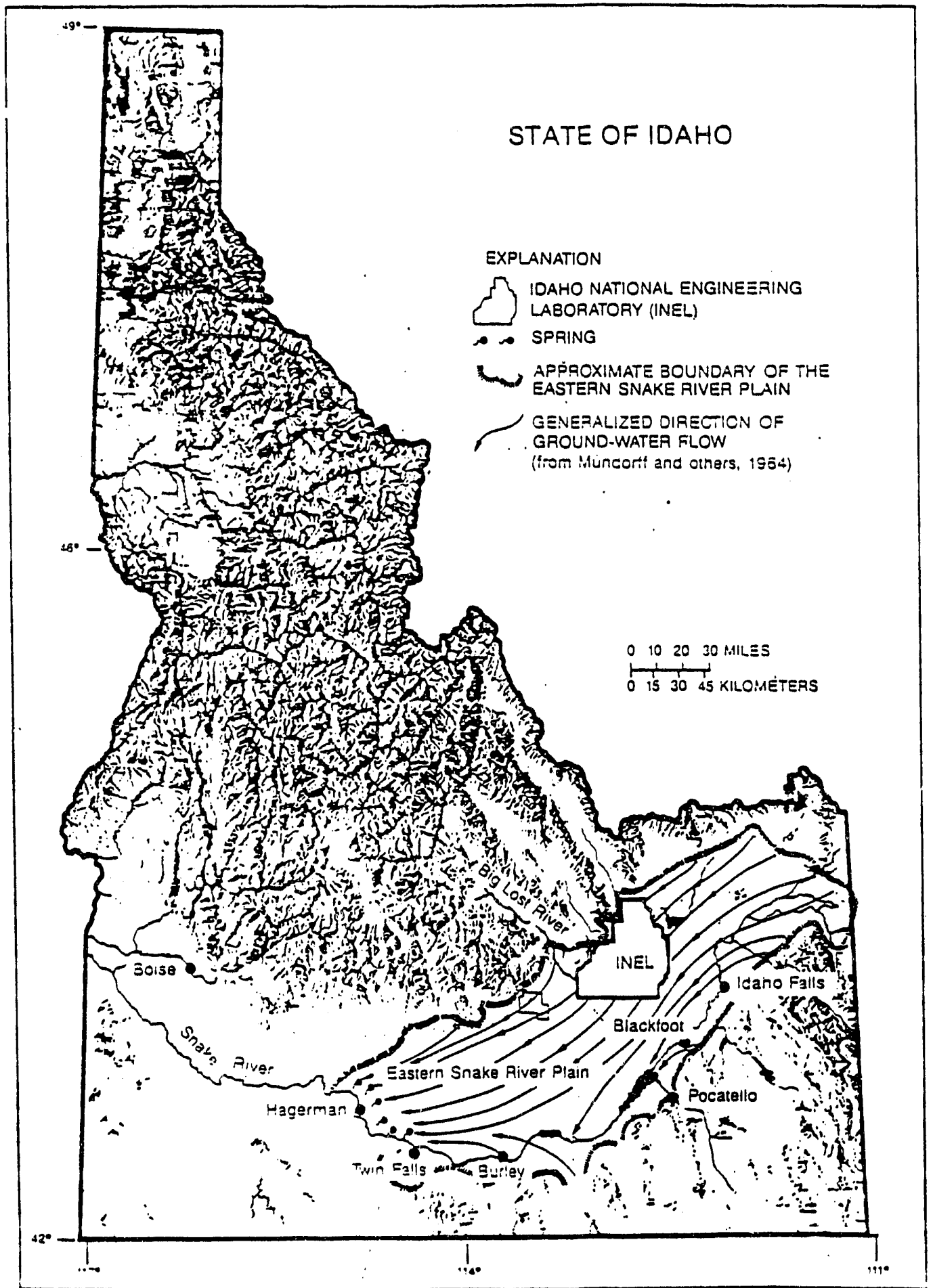

Fig. 1. Locations of the INEL and Snake River Plain, and generalized direction of ground water flow in the aquifer (Barraclough' et al, 1981). 


\section{Surface Water}

Streams draining the mountains and valleys to the west and north of the INEL (Fig. 2) are a source of irrigation water in agricultural areas adjacent to the INEL. Snowmelt and rainfall contribute to surface water, especially in the spring. The Big Lost River is an important source of groundwater recharge at the INEL. The Big Lost River flows southeastward in its valley past Arco, onto the Snake River Plain, and then turns northeastward through the INEL to its termination in three playas (Fig. 2). The river loses water by infiltration through the channel bottom as it flows onto the plain. As flow approaches the playas, the channel branches into many distributaries, and the flow spreads over several flooding and ponding areas (Barraclough et al, 1967). Recharge to the Snake River Plain aquifer from flow in the river during wet years is significant. During dry periods, streamflow does not reach the INEL because of upstream diversions for irrigation.

Mackay Dam, $30 \mathrm{mi}$ upstream from Arco, and the flood-control diversion dam in the southwestern part of the INEL (Fig. 2) affect flow in the Big Lost River. The flood-control diversion dam was constructed in 1958 to reduce the threat of flooding at INEL facilities near the Big Lost River. The diversion dam diverts flow from the river channel into spreading areas A, B, C, and D (Fig. 2). During winter months, nearly all flow is diverted to avoid accumulation of ice in the main channel, thus reducing the possibility of flooding at INEL facilities.

From 1965 to 1985, the annual flows of the Big Lost River below Mackay Reservoir generally were higher than those prior to 1965. In order of decreasing magnitude, 1984, 1965, 1969, 1983, 1967 , and 1982 were the six highest annual flows of record. Three of the six highest annual flows occurred in three consecutive years--1982, 1983, and 1984--with 1984 being the highest since records began. Annual flows from 1982 to 1985 were $328,000,372,000,476,000$, and 262,000 acre-ft, respectively, and exceeded the 69-year average of 227,500 acre-ft.

\section{GROUND WATER MONITORING NETWORKS}

An extensive ground water monitoring program has been developed since the early 1950s. This is described by Pittman et al (1988). Two ground water monitoring networks have operated at the INEL: a water-level network and a water-quality network. Data collected from these networks are on file at the U.S. Geological Survey's INEL project office. The water-level network is designed to determine the changes in hydraulic gradient that influence the rate and direction of ground water and radionuclide movement, identify sources of recharge, and measure the areal extent of the effects of recharge. Water levels are measured in both the Snake River Plain aquifer and perched ground water zones. The location 


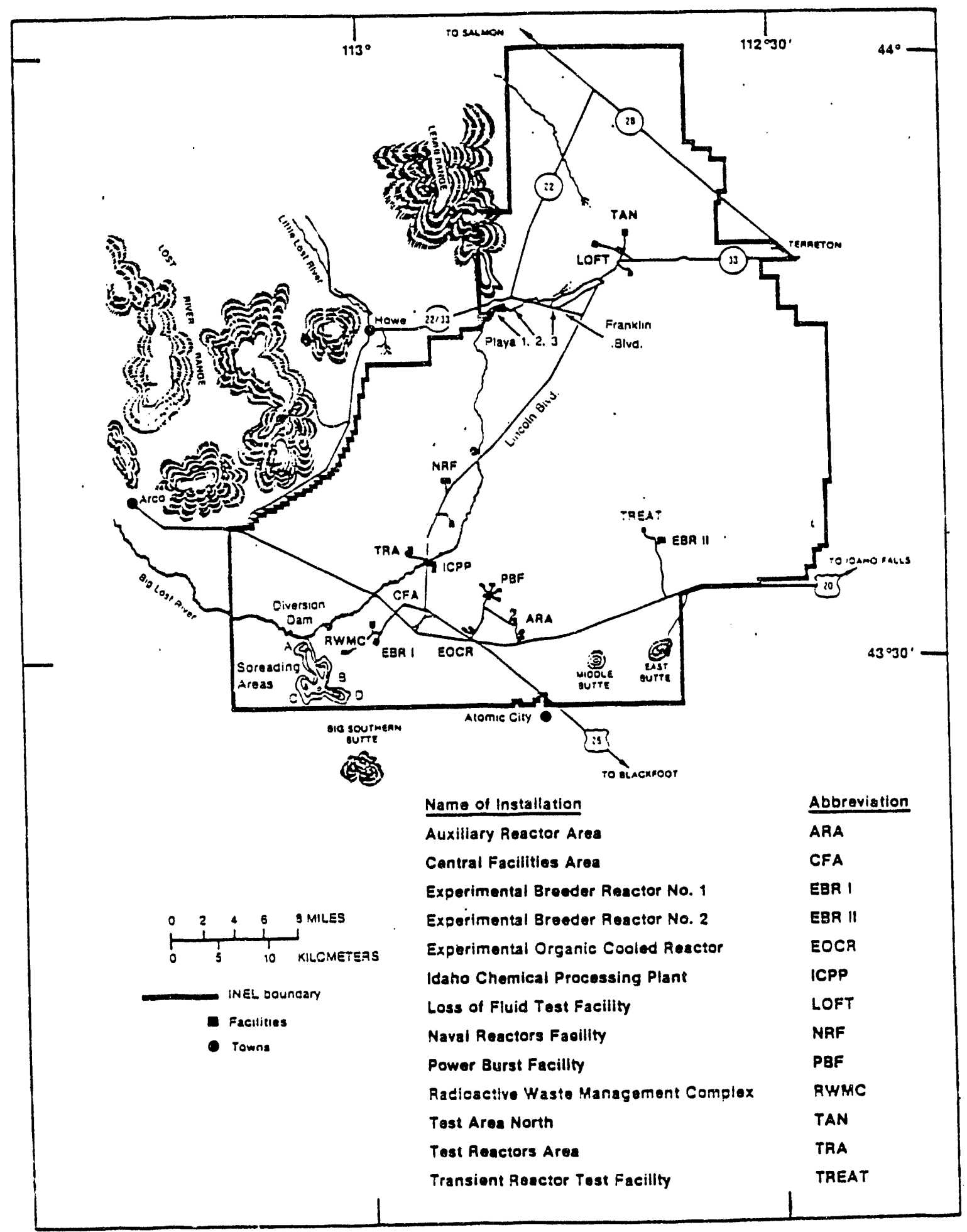

Fig. 2. Location of selected INEL facilities (Pittman et al, 1988). 
of observation wells and the frequencies of water-level measurements are shown in Figs. 3 and 4.

The chemical and radiochemical character of ground water at the INEL is determined from analyses of water samples collected as part of a comprehensive sampling program. The type, frequency, and depth of sampling depends on the information needed in a specific area. The program includes analyses for tritium, strontium-90, cobalt-60, chromium-51, cesium-137, plutonium-238, plutonium-239,240 (undivided), americium-241, total chromium, specific conductance, sulfate, chloride, nitrate, and 28 other chemical constituents or properties.

Water samples are collected at the INEL and adjacent areas to define the chemical character of ground water entering and leaving the INEL. In addition, nearby surface water sites are sampled to document the chemical quality of water that recharges the ground water system. Numerous samples are collected near areas of detailed study, such as the Test Reactors Area (TRA) and the Idaho Chemical Processing Plant (ICPP), to identify the contaminant concentrations and to define the pattern of waste migration in the Snake River Plain aquifer and perched ground water zones. The location of well and surface water sites, and the frequency of sampling on or near the INEL are shown in Figs. 5 and 6.

This report is organized in two parts; 1) the review of the unsaturated zone at the areas in which there was significant disposal of radioactive or chemical wastes; 2 ) the review of recharge from the Big Lost River.

\section{UNSATURATED ZONE}

by

\section{Brad King and George Bloomsburg}

During the first several decades of the INEL most of the hydrologic research was conducted by the U.S. Geological Survey (USGS). During the last 10 to 15 years hydrologic research has also been conducted by INEL personnel. Originally, the disposal of low-level radioactive waste water by infiltration into the ground was done under the assumption that the waste water eventually will reach the regional water table, but that the lapse of time, ion-exchange with earth materials, and dilution would reduce the radioactivity to the extent that it would not cause serious deterioration of the quality of the regional ground water supply. Waste water disposal at the Test Reactors Area (TRA), Idaho Chemical Processing Plant (ICPP) and the Naval Reactor Facility (NRF) comprises 80 to 90 percent of the total waste water at the INEL and have the best documentation. Waste water disposal at the TRA and the ICPP comprise 70 to 80 percent of the total waste water at the INEL. A good summary of waste wate: disposal activities and their influence on the geochemistry of the water at the INEL from 1952 to 1970 is presented by Robertson et al (1974). Tritium as a radioactive waste product was not detected until 


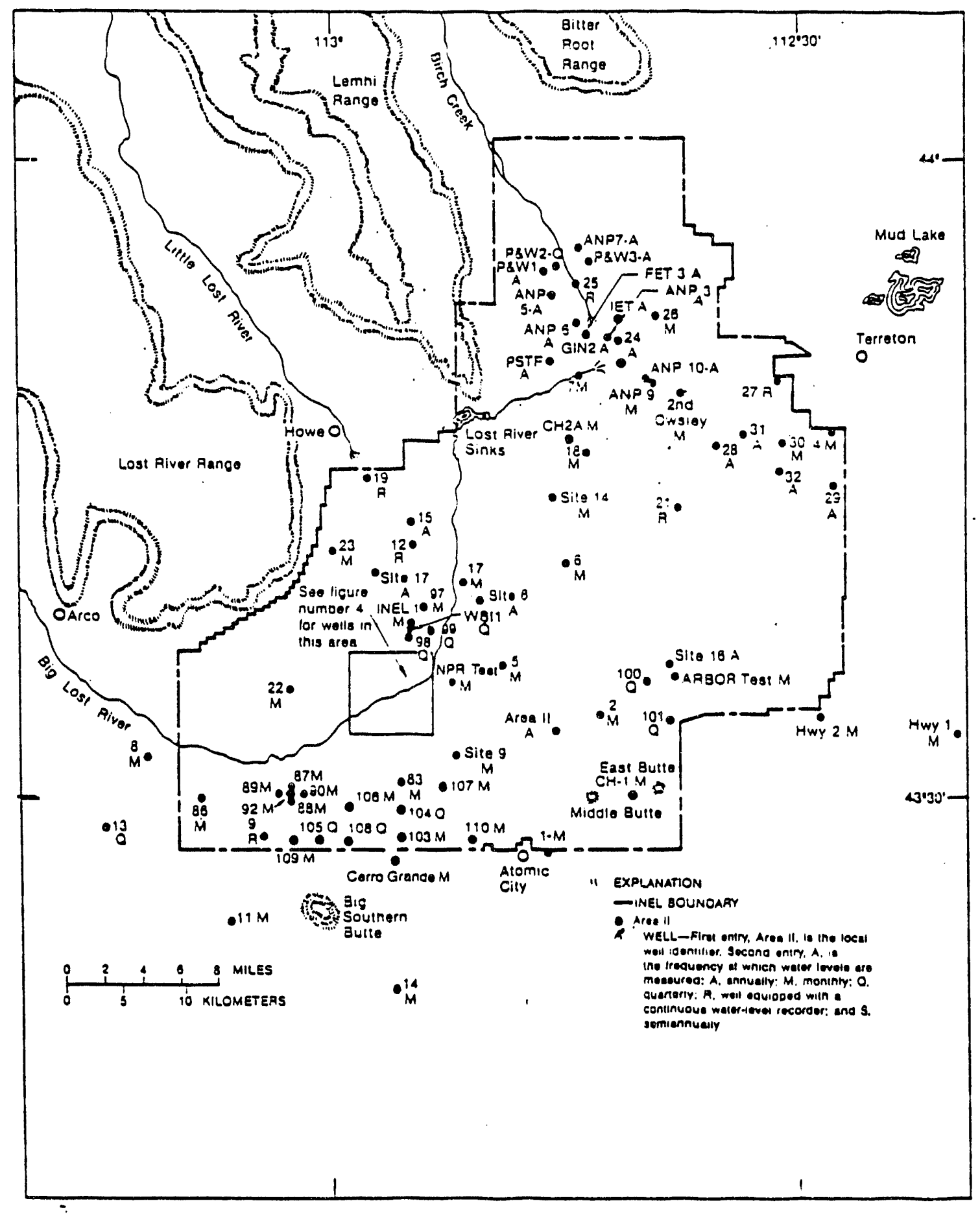

Fig. 3. Lovations of wells and frequdencies of water-level measurements at the INEL and vicinity (Pinman et al, 1988). 


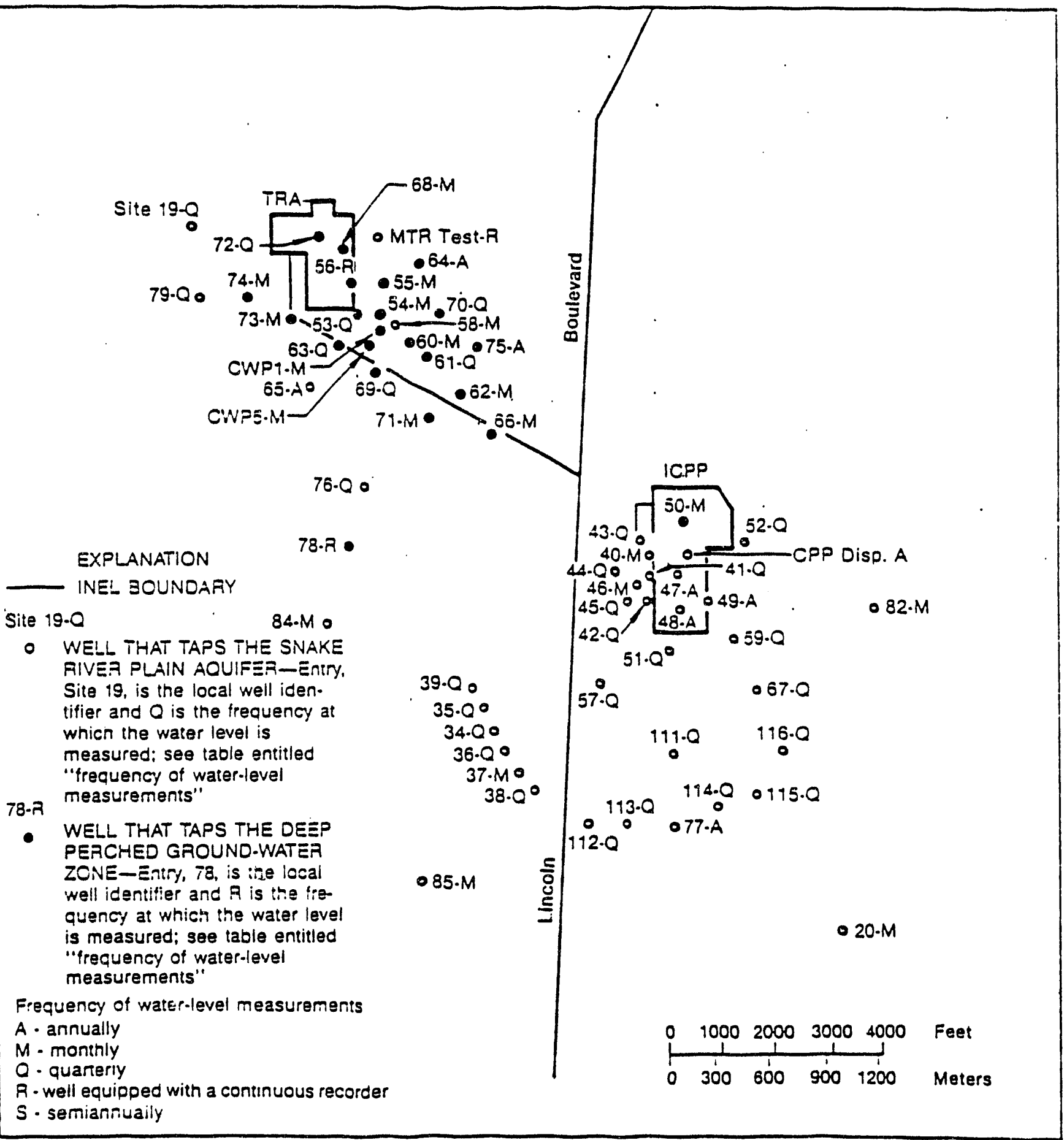

Fig. A. Locations of we!!s and fazencies of water-'evel measurements in the TRA-iCPP area (Pitiman et al, 1988). 


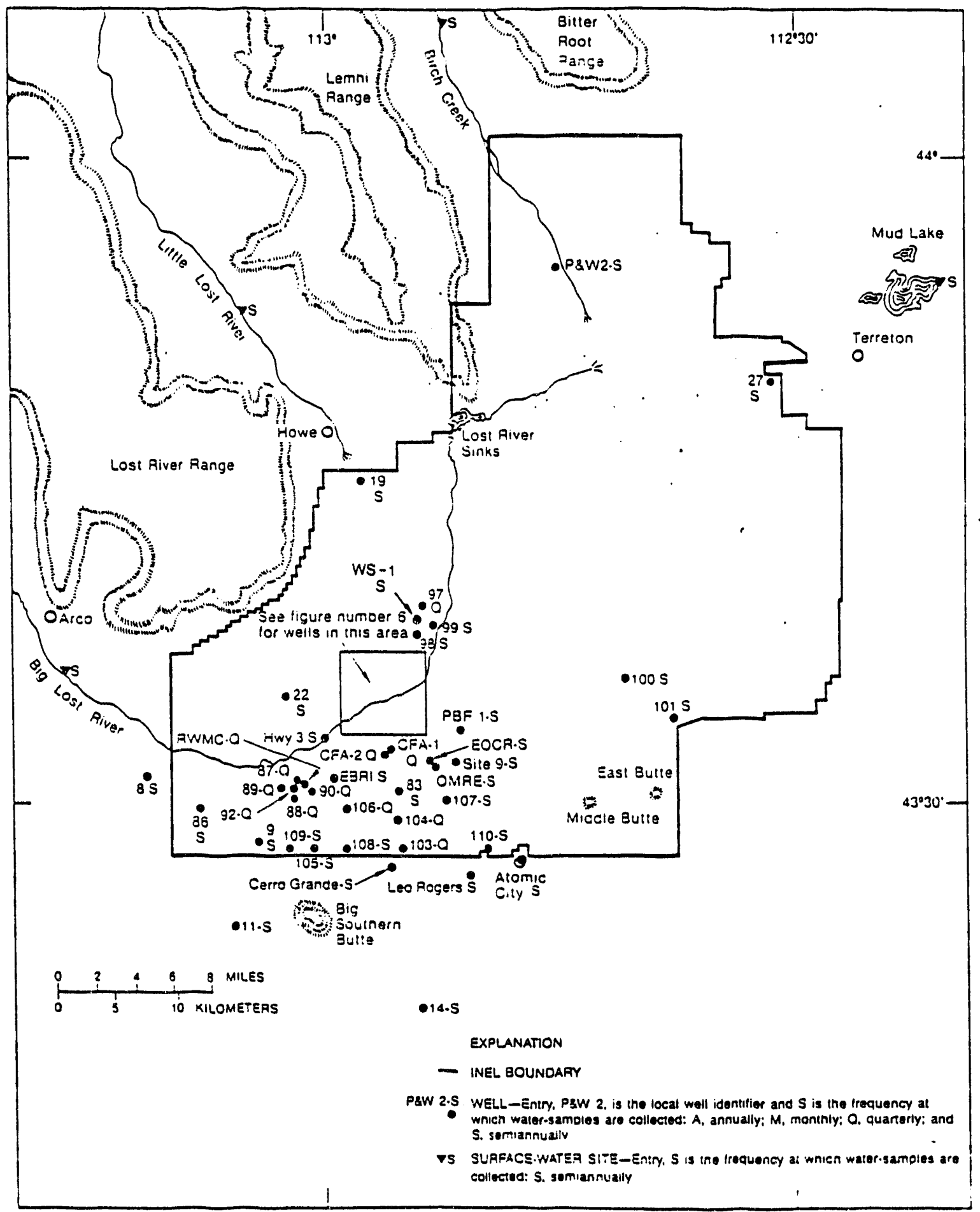

Fig. 5. Locations of wells and freqencies or water-sample collections at the INEL (Pittman et al, 1988). 


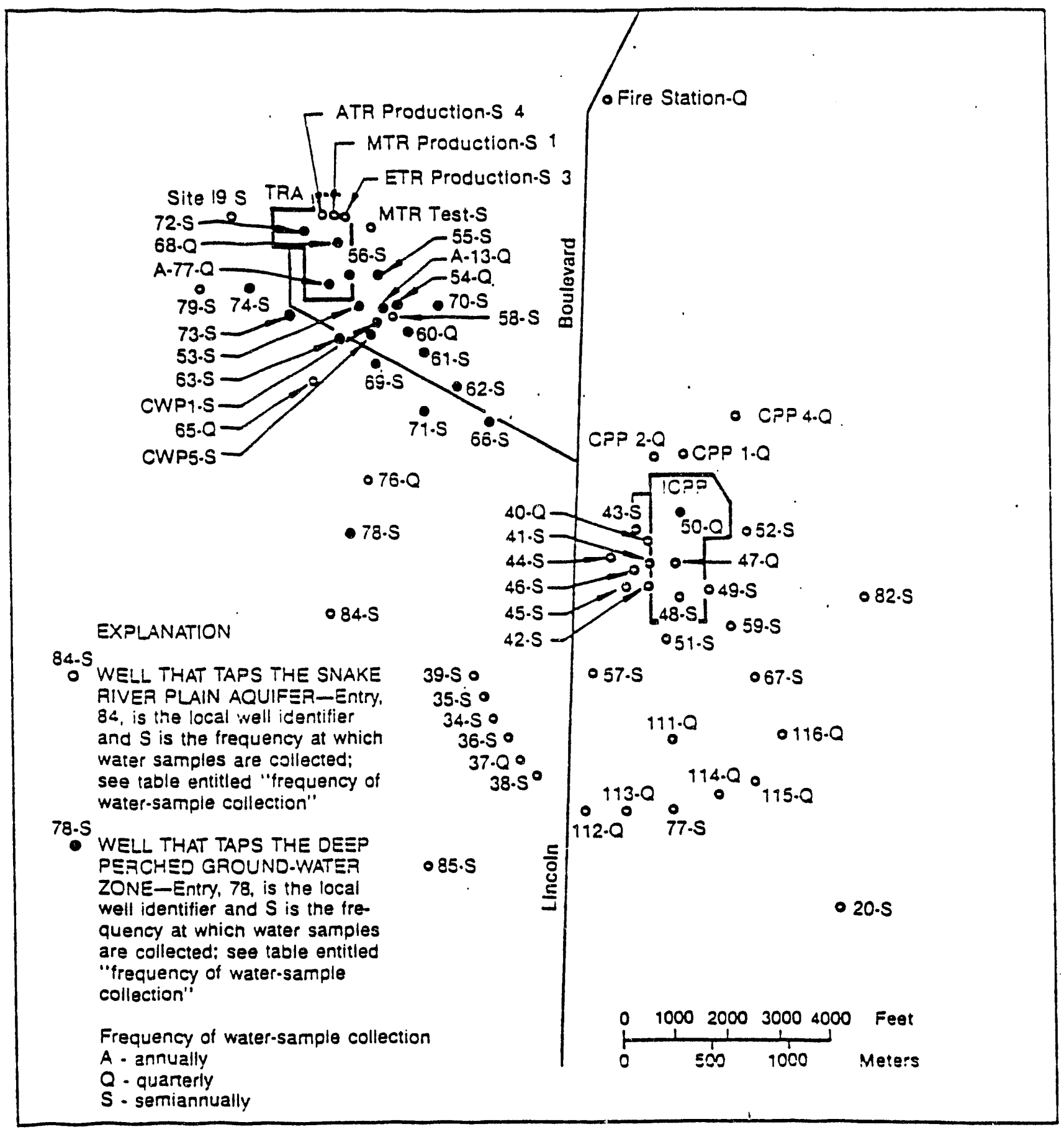

Fig. 5. Lucaticns of well and freqencies of water-sample collecticns in the TRA-ICPP area (Pittman et al, 1988). 
1960 although it was present from the start of operations. The volume and chemical constituents in waste ivater discharged from 1952 to about 1958 are not accurately known. However, since 1959 the volume and chemical constituents in waste water discharged to various points are generally available. Until the mid 1960's there was difficulty in measuring trace tritium concentrations, hence reported concentrations are uncertain. The series of annual reports published by the U.S. Geological Survey during the period of 1962 through 1966 contain information relating to the influence of recharge from various surface waters on perched and ground water levels. These reports also contain information about studies undertaken to determine travel times from waste water ponds and surface water recharge to perched water tables and the regional ground water tüble. The reports published by the U.S. Geological Survey from 1970 to 1985 concentrate on monitoring the location and form of perched and ground water tables and mapping of plumes of radioactive and chemical wastes in the perched and ground water tables. Since 1985, considerable effort has been expended in characterizing the Radioactive Waste Management Complex (RWMC), a disposal area for many cubic meters of primarily solid waste. Rainfall and water from flooding by the Big Lost River have leached material from the buried wastes into perched water zones.

\section{Test Reactors Area (TRA)}

Liquid low-level radioactive and chemical waste have been discharged to the subsurface at the TRA through ponds; while chemical wastes have been discharged to a deep disposal well. The use of the deep disposal well was discontinued in March 1982. Infiltration from waste water disposal ponds has formed a perched water body beneath the TRA facility. The water percolates almost vertically downward from the ponds through gravel, sand and silt to a basalt layer about 50 feet below the ground surface. The basalt layer retards the downward movement and forms a shallow perched water body. Water from this body seeps into the basalt and spreads to form a larger perched water body. The downward movement of the perched water in this body is retarded by a layer of clay and silt about 150 feed below the surface and 300 feet above the regional ground water table.

The layout of the TRA area disposal ponds prior to 1970 with the year of construction is shown in Fig 7. Initially, only one pond was used for waste water disposal (except sanicary waste). Additional ponds were added over time due to reduction in pond infiltration rates and/or expansion of operations.

Jones (1961) describes the stratigraphy of the MTR-ETR area as evidenced by the dilling of 16 wells and 22 moisture-meter access holes in the vicinity of the radioactive waste pond. Water level data from the wells is used to construct a map showing the contour of the perched water table. No distinction 
is made between the perched water table bodies in the alluvium and basalt. It was noted that in a number of perched water wells, water was not evident as the hole was deepened through hard, dense basalt. But, when the bit entered an underlying bed of scoria, cinders, or fractured basalt, the water entered the well and rose several feet, where it stabilized. In at least one instance, the height of rise was so great that the level stood above a bed of dry scoria and cinders above the dense basalt layer, but in a short time the water level declined to a new level as a consequence of drainage into the upper bed. To determine whether other perched water zones exist beneath the first extensive sediment bearing bed, and to investigate the possibility that waste water from the pond had reached the regional ground water reservoir in the vicinity of the pond, well 58 was cased through the zone of perched water and deepened to 475 feat - about 15 feet below the regional water table. No other zones of saturation were found above the regional water table. Samples of water collected from the regional ground water reservoir at well 58 did not indicate contamination by MTR-ETR waste water.

Morris et al (1963) describes an extensive study of the hydrology of the radioactive waste ponds. As part of the study, tests were conducted to evaluate the travel time for waste water from the radioactive waste ponds. Travel time was estimated by monitoring tritium concentrations in the pond water and wells. The results indicated average travel rates of 1 to $10 \mathrm{ft} /$ day. Fluorescein dye was used to determine the rates of horizontal movement within the perched water body in the alluvium. The dye was detected in wells 35 feet away less than one-half hour after injection. The dye was detected in a well 75 feet away in two waves, 3-1/2 hours and 7-1/2 hours after injection. A total of 37 shallow test holes augured to the basalt layer near the radioactive waste pond were completed by the end of 1962 . Samples of the bore-hole materials from the wells were analyzed for physical characteristics including particle size distribution and laboratory saturated hydraulic conductivity. Lithologic logs and material characteristics were presented for selected auger holes. The auger holes were used to monitor water levels, contaminant levels, soil moisture and radioactivity. A neutron probe was used to monitor soil moisture levels in the auger holes. Gamma ray logs of the holes were made to determine and monitor the location and extent of radioactivity. The combination of soil moisture profiles and radioactivity profiles were used to evaluate the behavior of unsaturated flow from the ponds. Contours of the perched water bodies in the alluvium and the basalt layer were made as well as a plume contour for tritium from the radioactive waste water pond. The results showed that leakage was occurring within the TRA compound and that the total volume of waste water was not known. On about November 10,1962, demineralized waste water (acid and chemical wastes) was diverted to a separate pond.

Morris et al (1964) presents a contour map of specific conductance of the perched water table. 


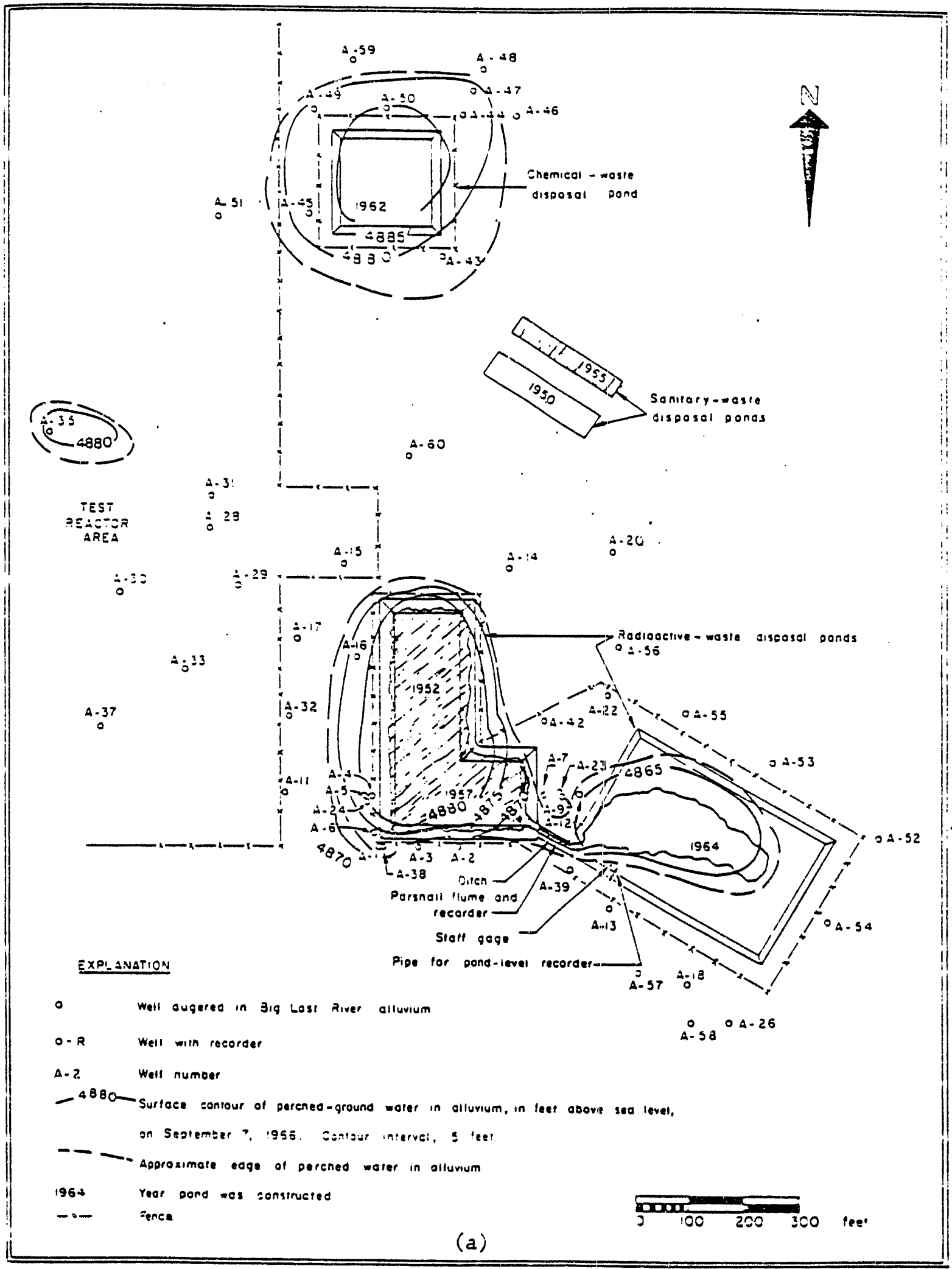

Fig. 7. Map of the TRA showing the lovation of disposa! ponds, augar holes, and the extent and waterleve contours of the perched water table in the alluvium on Sept. 7, 1966 (Robertson et al. 1974). 
A large leak in the pipeline carrying radioactive waste to the ponds was found. Several perched water table contour maps are presented showing the change in the perched water table preceding and following the repair of the pipeline. As a result of fixing the leak the pond level rose several feet prompting the need for an additional pond. It was concluded that the leak had occurred for years and that the volume of radioactive waste water for previous years was not known. A volume balance analysis on the perched water tables revealed that the perched water table in the alluvium ( $25 \%$ effective porosity) was only large enough to hold about two to three weeks worth of waste and the perched water table in the basalt (3.5\% effective porosity) was equal to about $1-1 / 2$ years of waste discharge and at most (10\% effective porosity) 4 years of waste discharge. Thus, it was concluded that leakage to the regional water table probably has been occurring for years through the sedimentary beds and down well bores. On February 23, 1963, a fission break occurred at the facility causing the release of high radioactivity to the waste ponds. The waste contained $\mathrm{Ce}^{141}, \mathrm{Te}^{132}, \mathrm{I}^{132}, \mathrm{Ba}^{140}, \mathrm{La}^{140}, \mathrm{I}^{131}$, and $\mathrm{Sr}^{90}$. This surge in radioactivity was monitor ad in several wells to investigate the migration of this radioactive surge. These data were presented but no resulting conclusions were made. The TRA disposal well was placed in service in October 1963.

Morris et al (1965) present changes and trends in water quality at the TRA. Radioactive waste water entered a newly constructed pond on June 30, 1964. Site selection was based on the high permeability of the soil and the need to avoid installed deep wells. The pond was designed for a longterm infiltration rate of $10 \mathrm{gpd} / \mathrm{ft}^{2}$. The inferred infiltration rate during the last half of 1964 was from 20 to $33 \mathrm{gpd} / \mathrm{ft}^{2}$. Water table rises in wells around the new pond as a result of water first entering the pond gave an effective travel time of about 50 feet per day. Perched water table contour maps for the alluvium and the basalt both before and after startup of the new pond are presented. Leakage within the TRA compound was again noted. It was also noted that since 1960 , chemical waste had been injected into well 53 which is 90 feet deep. Injection of about $100 \mathrm{gpm}$ (nearly 150,000 gpd) occurred from November 1960 to January 1962, from June 1963 to August 1963, and from November 1963 to September 1964. The water level rose from 20 to 40 feet above the static water level during injection indicating a specific capacity of about 2.5 to $5 \mathrm{gpm}$ per foot of injection head. Successful recompletion of the TRA disposal well made it capable of disposing of as much as $1,000 \mathrm{gpm}$ of cold waste. The well is 1,271 feet deep, cased to the bottom, and perforated at various intervals from 512 to 1,267 feet. Further iniection into well 53 was not expected. It was noted that well 66 apparently taps a perched water body 100 feet beiow the main perched wate: body.

Barraclough et al (1966) states that the infiltration from the chemical waste pond has caused a substantial change in the mineral content of the waters in wells 8 and MTR Test, penetrating a perched- 
water table and the regional-water table, respectively. A second sanitary waste disposal pond was excavated and put in to service in 1965. The waste disposal well was used to dispose of 147 million gallons of waste during 1965, more liquid waste than any of the ponds. Eighteen new wells were augured to the top of the basalt to define the shallow perched water near the radioactive waste disposal and chemical waste ponds. Perched water table contours for the alluvium and basalt are presented. Leakage within the TRA compound was still evident. The relationship between pond discharge and the water level in certain wells is presented. The relationship between recharge from the Big Lost River and the water level in certain wells is also presented. Travel times for recharge to various wells can be determined from the data collected. Maps of the tritium concentration and specific conductance in the regional ground water and the perched ground water are presented. Infiltration rates for the Big Lost River channel, playas and spreading areas are given as a result of the largest flow on record for the Big Lost River during 1965.

Barraclough et al (1967) presents perched water contours for the alluvium and basalt. Additional observations of the interaction between the perched water bodies the recharge from the Big Lost River are reported. Tritium contamination plumes in the regional aquifer and the perched water in the basalt are presented. A chromium contamination plume in the regional aquifer also is shown.

Robertson et al (1974) summarizes the influence of waste disposal at the TRA on the local hydrology. This includes volumes and concentrations of radioactive and non-radioactive discharges, relationships between pond discharge, recharge from the Big Lost River and the levels and extent of perched water bodies. Contours of the perched water bodies in the alluvium and basalt are presented. A generalized stratigraphic cross-section of the TRA from the report is shown in Fig. 8. Well 66 is shown in Fig 8 to intercept a deeper perched water body. A brief description of ion exchange and sorption for $\mathrm{Sr}^{90}, \mathrm{Cs}^{137}$, and $\mathrm{Co}^{60}$ are presented along with a discussion of the effect on migration of these radionuclides. Similarly, a brief discussion is presented regarding chemical equilibriurn reactions with regards to $\mathrm{Cr}(\mathrm{III})$ and $\mathrm{Cr}(\mathrm{VI})$.

Barraclough and Jensen (1976) summarize waste disposal activities for the period 1971 to 1973 and present contours of the perched water bodies in the alluvium and the basalt under the disposal ponds. The perched water body was found to contain tritium, $\mathrm{Cr}^{51}, \mathrm{Co}^{60}, \mathrm{Sr}^{20}, \mathrm{Ce}^{137}$ and other non-radioactive chemicals. Plume contours for tritium, $\mathrm{Cr}^{51}, \mathrm{Co}^{60}$ and $\mathrm{Sr}^{30}$ in the perched water table in the basalt are presented.

Barraclough et al (1981) summarize waste disposal activities for the period 1974 to 1978 and present contours of the perched water bodies in the alluvium and the basalt under the disposal ponds. 


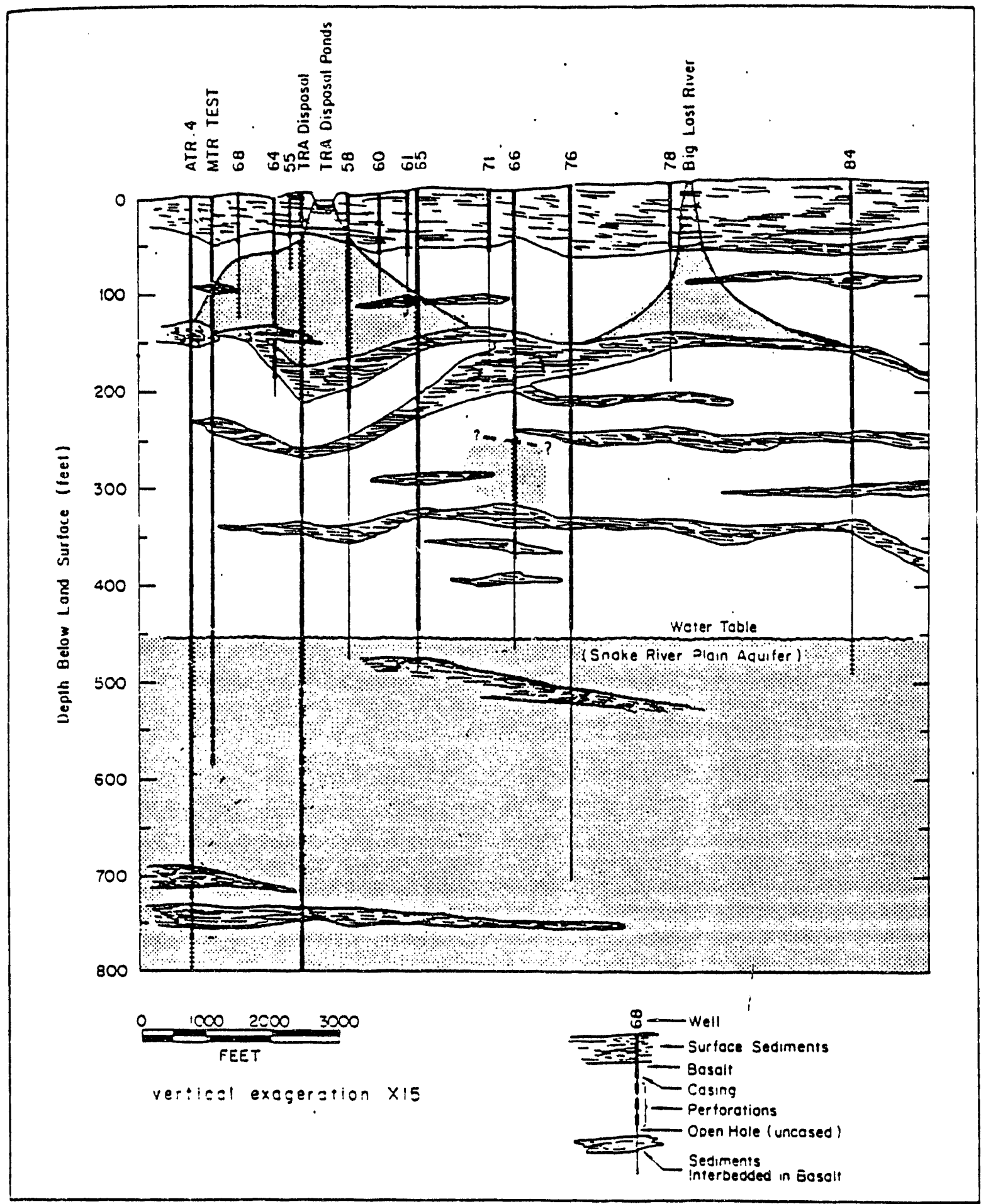

Fig. 8. Generalized stratigraphy of t.e TRA showing perched water, well and regional wate: table (Robertson et al, 1974). 
The perched ground water body contains radioactive and non-radioactive wastes. Plume contours for tritium, $\mathrm{Cr}^{51}, \mathrm{Co}^{60}, \mathrm{Sr}^{90}$, specific conductance, sodium, chromium, chloride and sulfate in the perched water table in the basalt are presonted.

Lewis and Jensen (1984) summarize waste disposal activities for the period 1979 to 1981 and present a contour of the perched water body in the basalt under the disposal ponds. The perched ground water body contains radioactive and non-radioactive wastes. Plume contours for tritium, $\mathrm{Cr}^{51}, \mathrm{Co}^{60}, \mathrm{Sr}^{90}$, specific conductance, sodium, total chromium, chloride, sulfate, nitrate and phosphate in the perched water table in the basalt are presented.

Lewis et al (1985) provides a good summary of the aqueous radioactive- and industrial-waste disposal activities (volumes and radioactivity) at the INEL (all significant sites) through 1982 .

Pittman et al (1988) summarizes waste disposal activities for the period 1982 to 1985 . The character and radioactivity of the waste gradually changed from previous years. Water discharged to the radioactive waste ponds from 1974 to 1979 contained an average of about 2,250 Ci/year of activation and fission products. From 1980 to 1985 , the average annual discharge of activation and fission products was reduced to about $288 \mathrm{Ci}$. Prior to 1980 , about 70 percent of these products had a half-life of several weexs or less. The average amount of tritium discharged to the ponds from 1977 to 1981 was about 140 $\mathrm{Ci} /$ year. In $1982,515 \mathrm{Ci}$ of tritium were discharged; from 1983 to 1985 an average of $208 \mathrm{Ci} /$ year of tritium were discharged. Between 1974 and 1979, tritium comprised about 10 percent of the total liquid radioactive waste. In 1980, tritium was about 50 percent and from 1981 to 1985 it was about 90 percent of the total amount of radioactivity discharged to the disposal ponds. From 1982 to $1985,1,140 \mathrm{Ci}$ of tritium were discharged to the radioactive waste disposal ponds. The average disposal rate was 285 $\mathrm{Ci} /$ year which is a 98 percent increase over the $1979-81$ disposal rate of $144 \mathrm{Ci} /$ year. The disposal well was used from 1964 to March 1982 to dispose of about 250 million gal/year of non-radioactive waste water. Since March 1982, two ponds each about 200 by $400 \mathrm{ft}$ in size have been used to dispose of the waste water. The location of the new cold waste ponds relative to the other ponds is shown in Fig. 9. Most of the cold waste is from cooling tower blowdown, and contains a yearly average of about 510,000 lbs of sulfate and $50,000 \mathrm{lbs}$ of other chemicals. For several years, hexavalent chromium was used as a corrosion inhibitor in the cooling tower and was discharged to the well. Hexavalent chromium was replaced by a polyphosphate beginning in October 1972. The extent and contour of the perched ground water in the alluvium and the deep perched grcund water zone are presented. Plume contours for tritium, $\mathrm{Co}^{60}$, total chromium, sodium, chloride, sulfate, nitrate and physical characteristics specific conductance and temperature in the deep perched ground water are presented. 


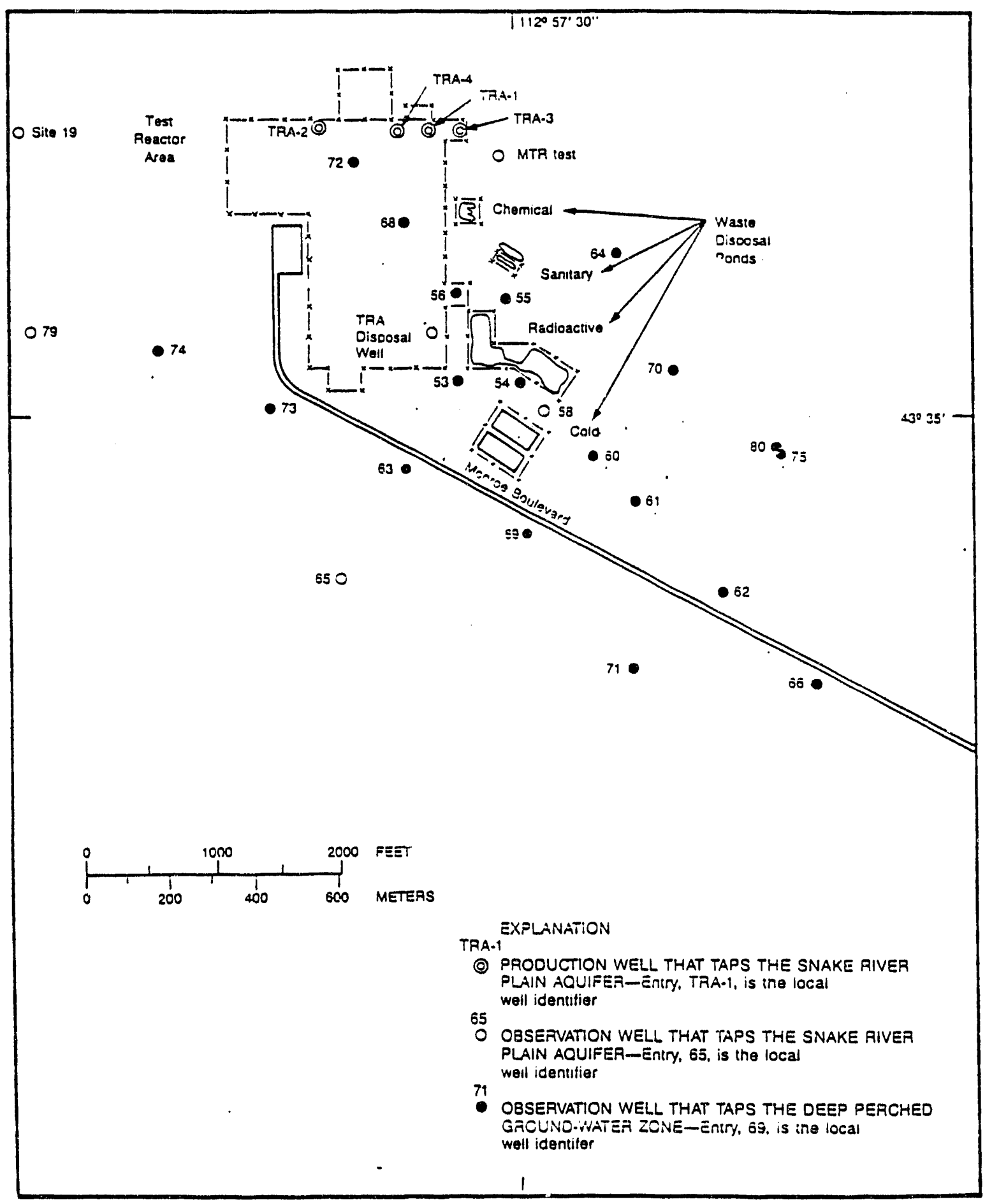

Fig. 9. Locations of cbserservation wells, production wells and waste disposal ponds at the TRA (Pittras et al, 1988). 
Hardy and Browder (1985) present a conceptual design report for the TRA radioactive waste cleanup. This modification provides for zero discharge of wastes into the environment. The wastewater will be treated under the Phase II modification and stored in tanks for re-use in selected systems. The untreated water is collected in tanks and routed through the TRA warm waste demineralizers. The deionized water is then to be stored in underground tanks and then to a storage tank for recycle to those areas that can use the treated water. Treated water will also be discharged directly to the evaporation pond to maintain a water balance.

A report by the Environmental Science Branch of DOE (1991) presents water chemistry data from several wells near the TRA.

Van Deusen et.al. (1988) describe the sampling that has been completed and the techniques used to mitigate sampling concerns in the corrective action investigation of the TRA Warm Waste Pond at the INEL. The Warm Waste Pond was designed to handle low-level radioactive wastewater and consists of three cells through which water infiltrated into the ground. Large gravel had been placed in the ponds to improve infiltration which made sampling the pond bottoms very difficult. The pond sludge contains chromium, mercury, lead, arsenic, berylium, cadmium, copper, silver, sulfides, organic carbons, zinc and hydrocarbines in concentrations above background.

\section{Idaho Chemical Processing Plant (ICPP)}

Waste water at the ICPP was discharged to a deep disposal well from 1953 to February 1984. Since then, unlined seepage ponds have been the main mechanism for waste water disposal at the ICPP, although the disposal well was available for use in emergency situations from 1984 to 1986 (Pittman et al, 1988).

Peckham (1959) states that for several years liquid wastes have been discharged to the ground through a disposal well and a shallow open-bottom manhole. Discharge from the plant through the disposal well averages about twenty-seven million gallons per month. This water is a complex solution of plant wastes, containing large amounts of sodium chloride used to regenerate four water-softening units. The disposal well is 598 feet deep, mainly in the Snake River basalt, and extends about 150 feet below the regional water table. which in this area is about 450 feet below land surface. The well is cased and gravel-packed throughout: about 40 feet of the casing is perforated above and about 100 feet is perforated below the regional water table to Fermit the waste to escape outward into the basalt aquifer. Sanitary wastes amounting to about one million gallons per month are discharged through a second openbottom manhole and a sewage effluent seepage basin. The open-bottom manholes are located near the 
cutting facility at the south end of the compound. The wastes disposed of in these and the seepage basin percolate downward through the alluvial gravel and sand of the Big Lost River and further through joints and other fractures in the basalt to the regional water table.

Jones (1961) briefly describes the stratigraphy of the ICPP area. The area is characterized as having 50 feet or less of alluvial material comprising the Big Lost River flood plain. Deposits beneath the alluvium, above the water table, include three groups of lava flows and flow units representing successive volcanic episodes. Beneath most of the ICPP area, these principal groups are separated by sedimentary beds.

Morris et al (1964) describes an investigation of radioactive wastes in the alluvium from the shallow disposal well with emphasis on the migration of $\mathrm{Sr}^{90}$ relative to $\mathrm{Cs}^{137}$. The main isotopes present in the disposal waste water are tritium, $\mathrm{Sr}^{90}$ and $\mathrm{Cs}^{137}$. Waste water goes directly into an intermediate manhole a'Jout 11 feet deep and then to the adjacent disposal well which is about 15 feet deep and five feet in diameter. Sewage and other plant wastes are passed through a septic tank, by passing the manhole into the disposal well. A total of 27 one-half inch observation holes were augured through the alluvium to basalt in the immediate area. The data are used to prepare contour maps of the perched water table, the configuration of the underlying basalt surface, and the areal distribution of radioactivity. The shallow disposal well is drilled into gravelly alluvium containing lenticular zones of fine-grained sediments or cemented gravels. The average thickness of the alluvium in the immediate vicinity is 33 feet. A water table contour map of the perched water body suggests two water tables, one about 10-15 feet higher than the other. Cross-sections of the area are presented showing the perched water bodies relative to the basalt. The areal extent and distribution of radioactivity in the immediate area is also presented. A waste water volume balance in the alluvium led to the conclusion that water was entering the basalt layer.

Barraclough et al (1967) summarize waste disposal activities for 1966 at the ICPP. Radioactive waste water disposal to the seepage pit was discontinued in September 1966.

Robertson et al (1974) provide a good summary of waste water disposal activities at the ICPP over the years 1952 to 1970 . The amount of tritium discharged before 1961 is not known because it was undetected. The seepage pit was reportedly discontinued in September 1966. However, the continued expansion of the perched water table and increase in radioactivity of the perched water body led to the conclusion that this was not the case. During the period of 1967 to 1968, the deep disposal well had unknowirgly collapsed and the subsequenily injected waste water at the 226 foot level of the unsarurated zone led to the contamination of the CPP-1 well. Periodic occurrences of contaminants in ICPP production wells has lead to the speculation of the source. Contours of the perched water table on 
various dates are presented. The general stratigraphy of the area is also presented, Fig 10.

Adamic et al (1984) reported the concentrations of mercury and cadmium in surface soils within the ICPP compound. Sampling depth was to $40 \mathrm{~cm}$.

The hydrologic assessment report by Hull (1987) provides some interesting material. The seepage pit was reportedly abandoned in February 1984 and waste water is now being sent to infiltration ponds just south of the ICPP. This water is beginning to create perched water tables both in the surficial sediments and in the basalt. These perched water tables are reportedly being monitored by the USGS. Stratigraphy of the ICPP area and the results of a simulation study by Thomas et al (1986) are discussed but the reference is not included in the report. Reference to a modeling study Robertson (1977) under seepage ponds at the TRA and related data on the hydrologic properties of the unsaturated zone used in the study are presented. The following quote is taken from the report:

"There is a very thick unsaturated zone at the INEL, which ranges from 200 to 1000 feet thick. This unsaturated zone is a complex sequence of basalt flows, breccia zones, and sedimentary interbeds. There is probably no movement of water through this zone under unsaturated conditions. The fractures and breccia zones in the basalt probably present too large a pore size for there to be a continuity of path under unsaturated conditions. Water probably moves down in discrete packets that saturate a small portion of the basalt. Drilling in the basalts in areas remote from discrete sources of recharge occasionally encounter areas of wet basalt. The quantities and rates of movement of this v/ater are unknown."

Reportedly the probability of flooding at the ICPP site due to high precipitation or from the Big Lost River has not been evaluated. Summary data on the physical properties (mineralogy, CEC and sorption coefficient, grain size distribution) of the alluvium at the ICPP are presented. Hydrologic data for alluvium at various sites in the INEL are also included.

Thomas (1988) has described the potential impacts of three alternative strategies being considered for the disposal of the ICPP high-level radioactive waste. One of the alternative strategies under evaluation is near-surface in-place disposal of the calcine waste presently stored in the Calcine Solids Storage Facilities. He reports on the modeling of the transport of three non-radioactive constituents from the calcine, due to rainwater recharge. The results of the modeling are intended to provide guidance for furure modeling studies and identify areas where more laboratory and field date are needed.

Navial Reaciors Facility (NRF)

The NRF has used unlined seepage ponds and a waste ditch for wastewater disposal since 1953 (Pittman et al, 1988). 


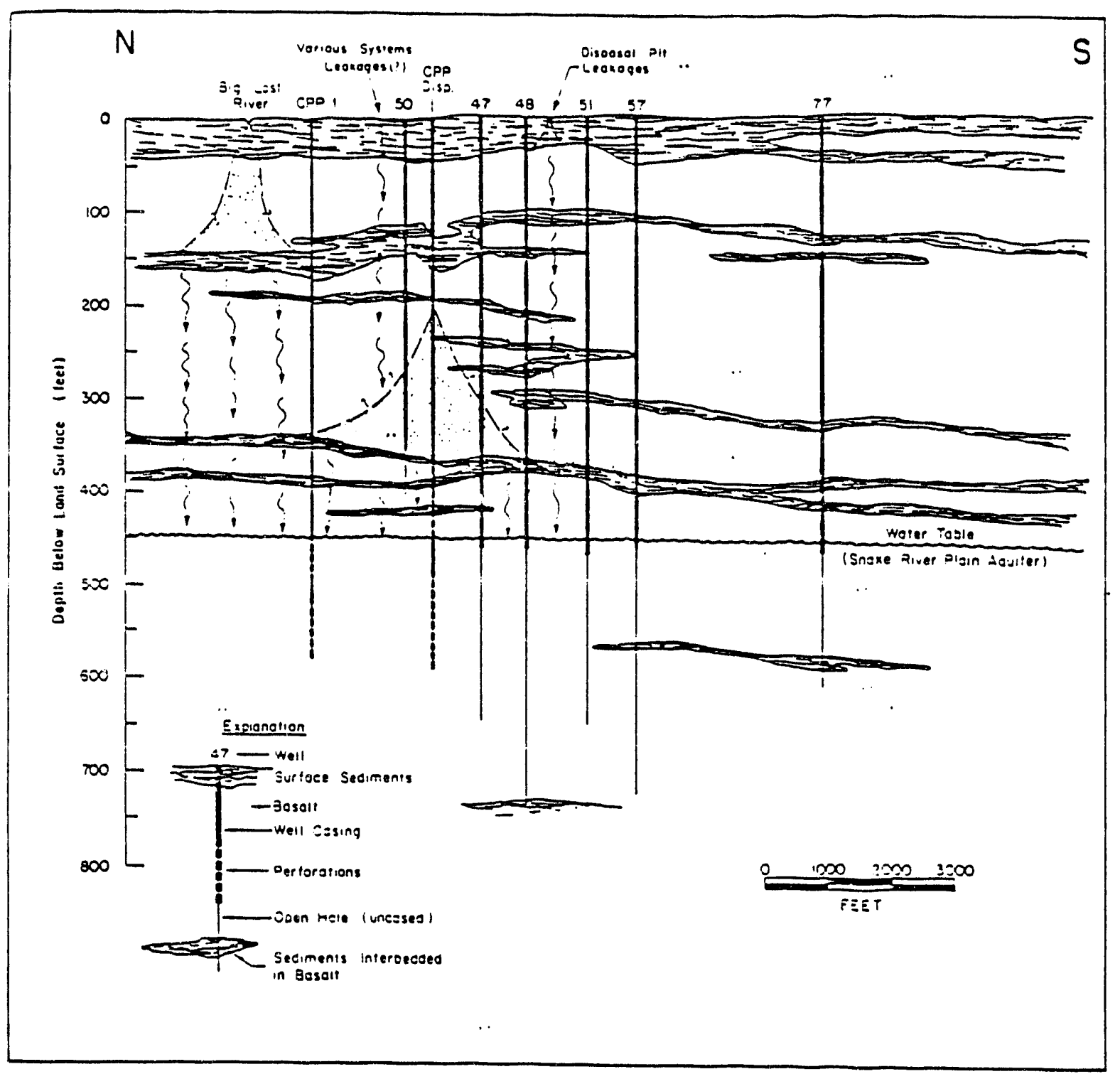

Fig. 10. Generalized stratigraphy of the ICPP area showing perched water, well and regional water table (Robertson et ai, 1974).

Morris et al (1964) reports the results of an investigation into the subterranean distribution of radioactivity at the NRF. The NRF facility reportedly disposes of its radioactive waste water by percolation into the ground by means of two infiltration pords. The ponds are exiavated into graveily ailuvium, which is a lizle more than 30 feet thick at one site and 10 to 20 feet thick at the other. The regional water table is a little more than 360 feet below the land surface at the NRF. The general 
locations of the ponds with respect to the NRF are shown in Fig 11. The S1W pond is located at the southeast corner of the NRF. The ECF-A1W pond is west of the NRF. Cross-sections through the ponds are presented. Twenty-five holes were augured through the alluvium to the basalt, 13 near the SIW pond and 12 by the ECF-AIW pond, to determine the extent of the radioactive contamination. These data are used to construct contour maps showing the configuration of the basalt surface and the perched water table. Samples of soil and water from the holes were used to prepare cross-sections showing the vertical distribution of radioactivity. The existence or use of a seepage ditch is not mentioned in the report.

Morris et al (1965) reports that four, 30-foot auger holes were drilled near the NRF sewage lagoon to aid in exploration of the movement of fluids in the vicinity. The location of the sewage lagoons relative to the NRF facility is shown in Fig. 12.

Barraclough et al (1966) reported that the holes drilled near the sewage lagoons were dry at the completion of drilling and again when checked in January 1966. The lagoon was built with an impervious bottom, and the dry holes indicate that little leakage occurs.

Robertson et al (1974) summarize waste disposal activities and investigations at the NRF. Reportedly since 1965 , the $S 1 \mathrm{~W}$ pond has been used almost exclusively, with the ECF-A1W pond being used only occasionally for unusual operational wastes. In addition to perched water under the ponds, it was deemed likely that a perched zone also occurs beneath the liquid industrial waste drainage-seepage ditch northwest of the NRF. The location of the drainage-seepage ditch relative to the NRF is shown in Fig. 13. This was the first report to mention the seepage ditch.

Lewis and Jensen (1984) reported that the NRF used a ditch to dispose of waste water, nearly 125 million gallons of wastewater annually for 1979 through 1981 . The waste water averaged about $168,000 \mathrm{lbs}$ of sodium, $217,000 \mathrm{lbs}$ of chloride and $366,000 \mathrm{lbs}$ of sulfate annually. The volume of liquid waste decreased in later years. Seepage ponds are used for sewage disposal.

Lewis et al (1985) reported that chemical wastes have dominated the effluent over the later period of record with little or no radioactive wastes having been discharged.

Pittman (1988) reported that the NRF uses a 3-mile long ditch to dispose of most waste water, although ponds are used for sewage disposal. The major chemical constituents in the waste water are sulfate, chloride, and sodium.

DOE presented a sampling plan in 1989 to Frovide background if necessary for preliminary investigations at selected TAM waste units. The surficial alluvial deposits above the upper basalt will be sampled. 


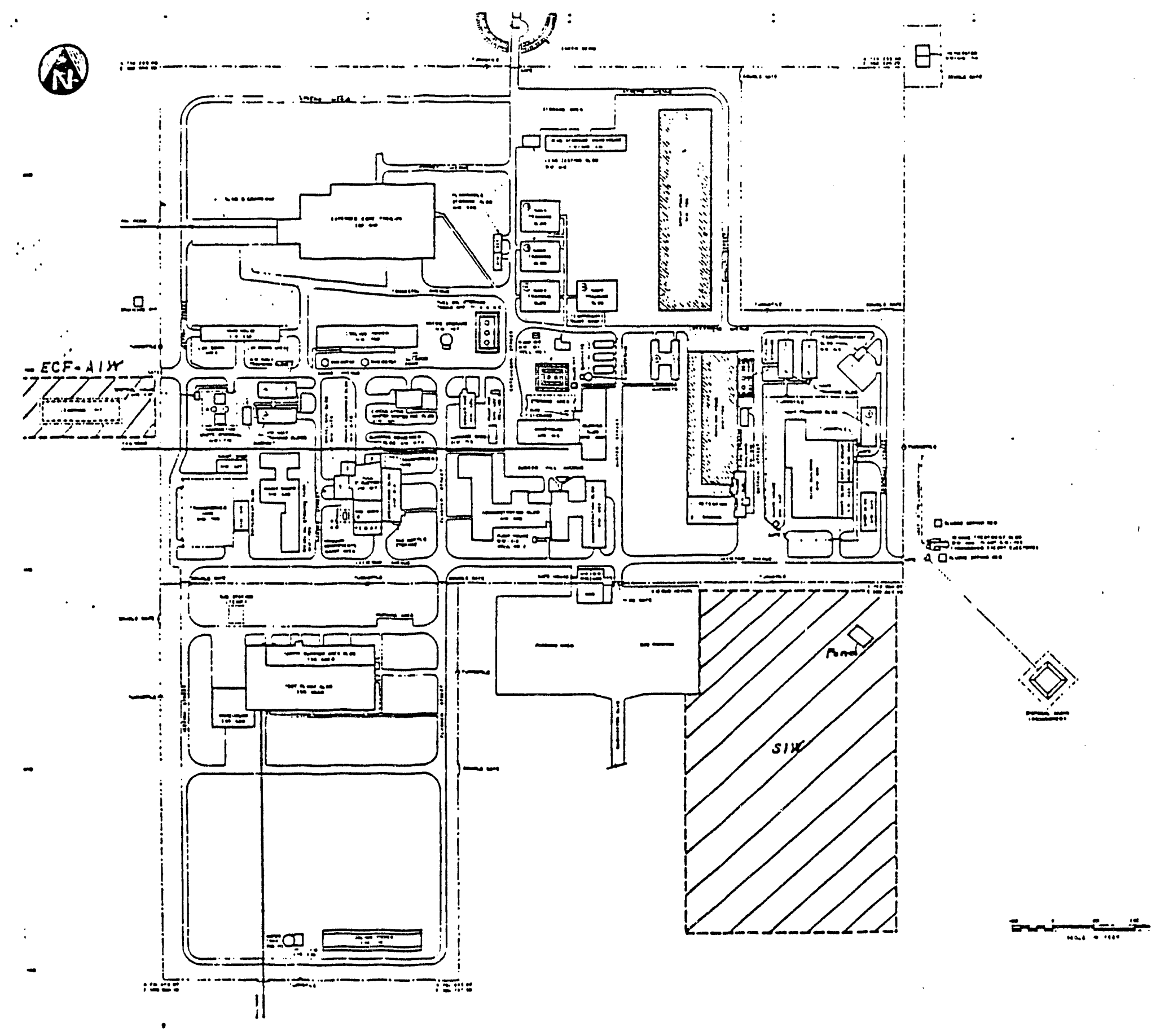

Fig. 11. Lecation of saepage ponds at the NRF (Morris et al, 1964). 


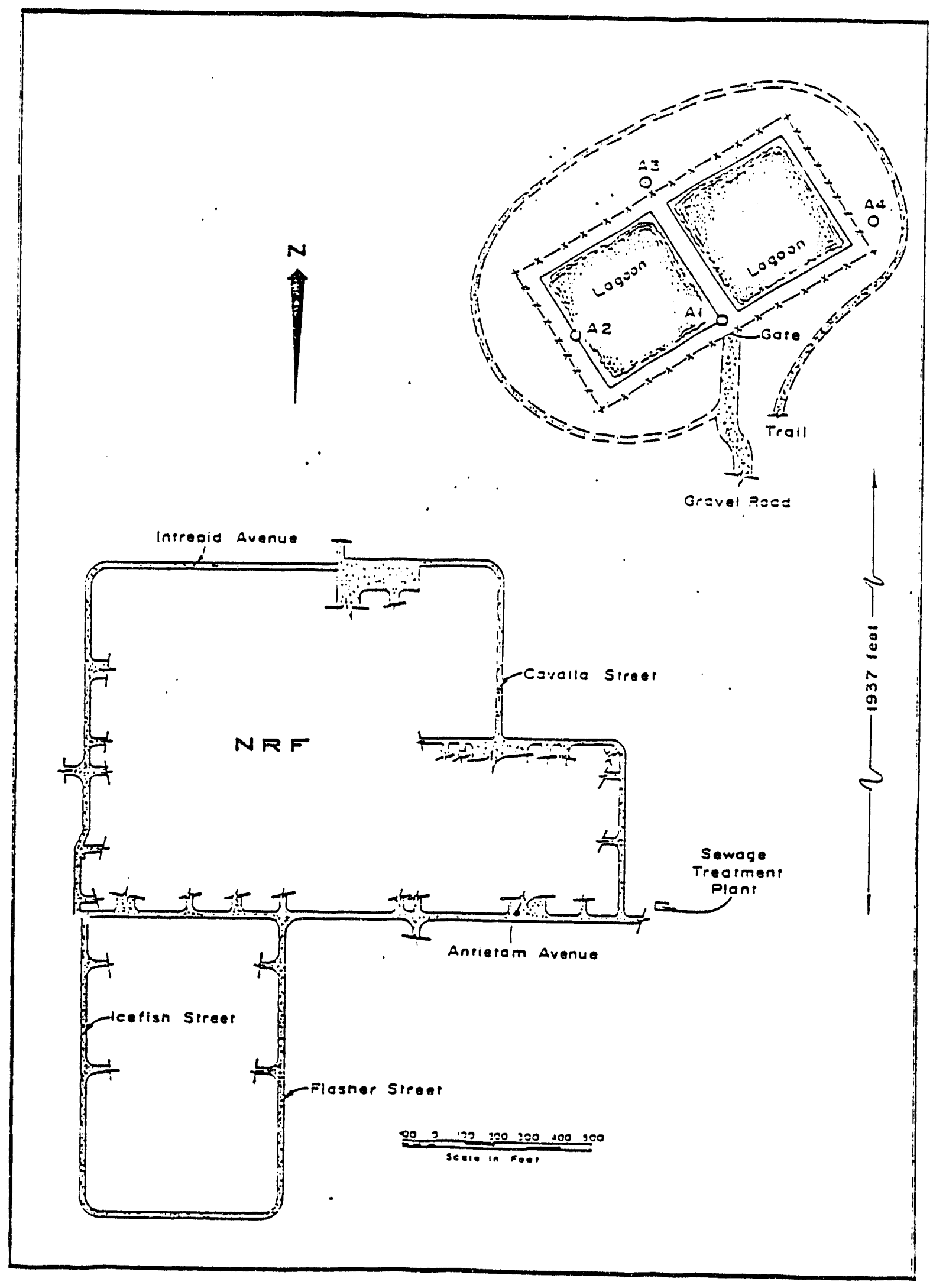

Fig. 12. Location of sewage lagoon area at the NRF (Morris et al, 1965). 


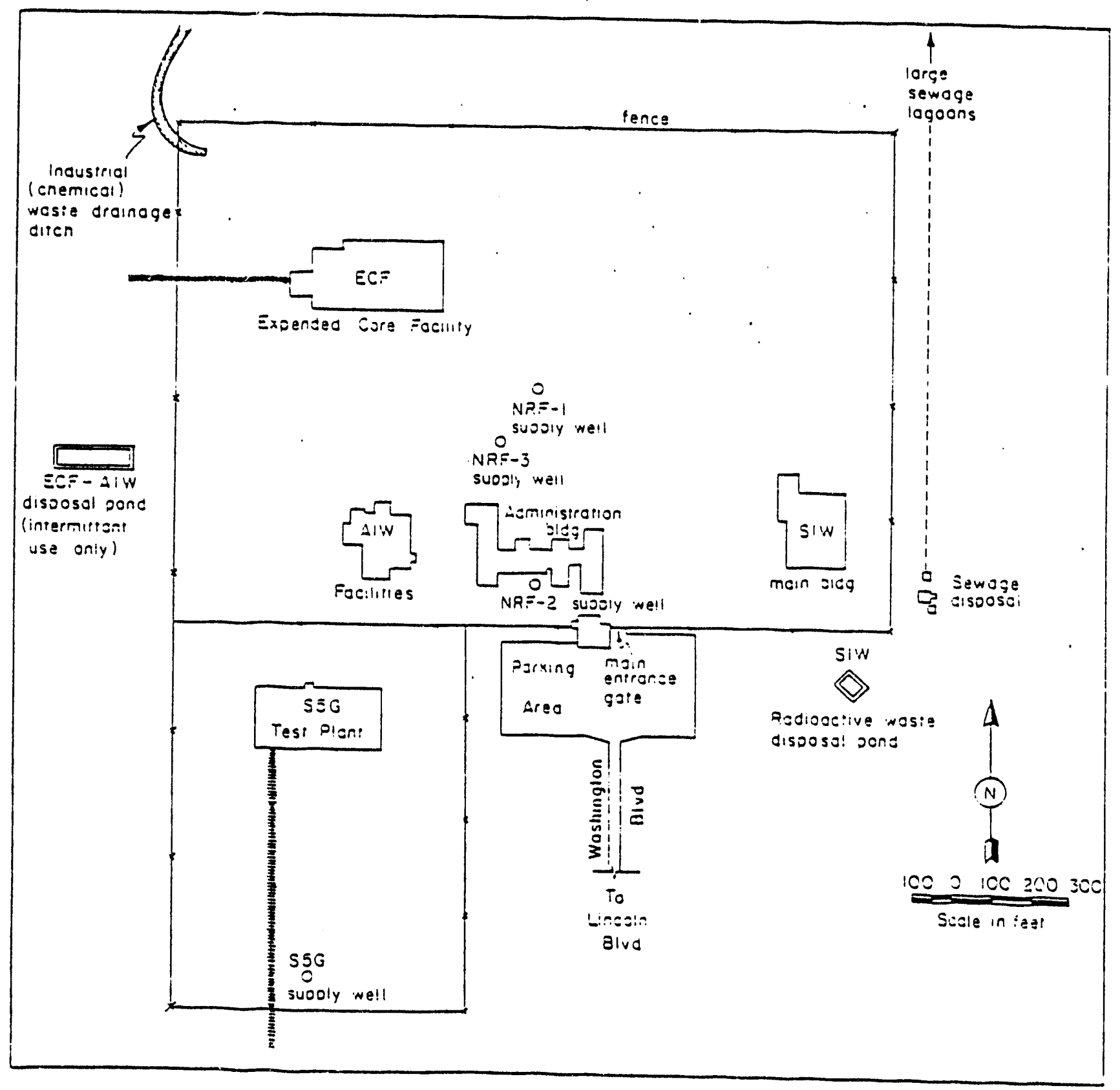

Fig. 13. Lccation of waste drainage ditch at the NRF (Robertson et al, 1974). 
Other Facilities

Morris et al (1964) presents the results of a study of the geology and hydrology of the LOFTTAN area. This includes results of drilling and corresponding physical properties of the material (grain size, saturated hydraulic conductivity, etc). Similar results for other scattered sites around the INEL are also presented.

Morris et al (1965) presents the results from drilling five wells in the TAN area to investigate the feasibility of injecting radioactive gas underground for temporary storage. The physical properties of the materials obtained frum the wells are given. The physical properties from drilling at other scattered sites around the INEL are also presented.

Barraclough et al (1967) reported that radioactive liquid waste discharges occurred at EBR-II, Spert and TAN but details of the disposal facilities are not presented. The results of gas injection tests in the Birch Creek Playa ars presented.

Robertson et al (1974) reports that liquid waste discharges occur at CFA, EBR-II, TAN, SPERT and ARA. At the EBR-II, site liquid wastes are discharged to seepage ponds. The discharges are relatively low so that any perched water system would be correspondingly small. Future discharges of liquid wastes are likely to 0 :cur at the PBF near the SPERT area. PBF will use two shallow wells, 110 and 115 feet deep, to dispose of low-level radioactive wastes and corrosive liquid wastes, respectively. The wells are purposely designed to allow the waste water to perch, thus reiarding percolation to the regional ground water table, which is about 450 feet deep. The LOFT at TAN will use a seepage pond for disposal of its low-level radioactive and chemical wastes.

Lewis et al (1985) reports that at the Central Facilities Area (CFA), radioactive- and chemicalwaste effluent from a laundering process was processed and diluted in a sewage treatment plant. From here, the liquid wastes are discharged to a shallow drain fieid to percolate to the regional water table about 480 feet below. The PBF utilized two shallow wells, 11.0 and $115 \mathrm{ft}$ deep for low-level radioactive waste and corrosive liquids. However, now lined evaporation ponds are used.

The CFA also has at least two landfills. Landfill II consists of a former gravel pit which was filled with waste and then covered by means of a bulldozer. Landfill III consists of a series of trenches which were filled and covered. There are a series of reports on the effort to determine the location and type of waste in the two landfills.

Ansiey, at al (1988) report on the gzologi: and hydrologic characterization of the shallow surficial material at the CFA landfills II and III. They also quantify the amounts and rates of water infiltration into the sediments and sample for contariinants in the sediments and in the soil gas. Heat dissipation 
probes were used for determination of moisture content and soil moisture tension. The results from these devices were not satisfactory. Soil samples were measured for bulk density, porosity, moisture content, moisture tension, hydraulic conductivity and grain size distribution. Neutron probes also were used for moisture measurement. Salinity sensors showed a wide range of specific conductance but indicate a significant migration of leachate with dissolved solids. Chemical analyses included antimony, arsenic, lead, selenium, cadmium, aluminum, copper, iron and vanadium. Gas sampling included analysis for about ten different hydrocarbons.

DOE (1990) presents a quality assurance plan for the ground water sampling at Landfills II and III. This report describes the sampling and data collection program as well as the project organization, sampling and analysis strategy, equipment and quality assurance program.

Ansley (1990) presents the technical work plan for the hydrogeological characterization of the landfills. This TWP establishes and documents the methods and procedures that will be used to accomplish the tasks outlined in the ground water monitoring plan and is designed to give direction to personnel in the field and to ensure that standard methods of investigation are used during field activities.

\section{Radioactive Waste Management Complex (RWMC)}

The RMWC occupies 144 acres of the INEL. From 1952 to 1970, low-level radioactive and transuranic waste were buried in pits and trenches excavated into a veneer of surficial sediment. Since 1970, low-level radioactive waste has been buried and the transuranic waste has been stored on aboveground asphalt pads in retrievable containers. From 1952 to 1986, about $180,000 \mathrm{~m}^{3}$ of low-level and transuranic radioactive waste containing about 9.5 million curies of radioactivity were buried at the RWMC. An estimated 335,000 liters of organic waste were also buried before 1970 (Pittman, 1989). The RWMC has been flooded by snowmelt in 1962, 1969 and 1982.

Nace et al (1956b) presents logs of test holes and test pits in and near the Burial Ground.

Hubbell et.al. (1985) describes the work that was accomplished during 1985 in the annual progress report for the RWMC. Twenty-two shallow auger holes were drilled around the RWMC to evaluate radionuclide content in the surficial sediments, to determine the geologic and hydrologic characteristics of the surficial sediments and to provide monitoring sites for moisture movement in the sediments. Porous cup lysimeters were installed to collect soil water samples from the surticial sediments. Fourteen auger holes were instrumented with tensiometers, gypsum blocks and psychrometers at various depths throughout the RWMC. Readings from these instruments were taken on a monthly basis. 
The 1986 annual report, Hubbell et.al. (1986), describes additional auger holes and the use of heat dissipation probes for measuring the moisture tension. The goal of the work at this time was to develop a field calibrated computer model to predict the long-term migration of radionuclides in the unsaturated zone and to measure the actual migration of radionuclides to date. Additional auger holes were drilled as well as three deep drill holes. Core samples were taken from several holes and the moisture characteristics evaluated with a pressure plate device in the laboratory. Weighing lysimeters in the field were measured every six hours. Soil water samples were collected from the sediments and analyzed. The TRACR3D computer code was tentatively selected for modeling at the site.

Rightmire and Lewis (1987) present the results of prior studies in their analysis of the hydrogeology and geochemistry of the unsaturated zone of the RWMC. Data from drilling programs is used to estimate the areal extent of each sedimentary unit and their physical characteristics. The location of wells in the RMWC is shown in Fig 14. Three main sedimentary interbeds (9, 34 and 73 meters) and thirteen basalt flows separate the land surface from the regional water table at a depth of about 180 meters. The $9 \mathrm{~m}$ interbed is thin but locally continuous under the RMWC. The $34 \mathrm{~m}$ interbed is absent under the older part of the subsurface disposal area. The $73 \mathrm{~m}$ interbed is of irregular thickness and is continuous under the entire RWMC and possibly much of the southeastern part of the INEL. The vertical hydraulic conductivity of the sedimentary interbed material is estimated to be in the range of $1.6 \times 10^{-7}$ to $3.0 \mathrm{~m} /$ day. The horizontal hydraulic conductivity in the cinder zones may be up to 5 or $6 \mathrm{~m} /$ day. Perched water bodies were encountered in numerous boreholes above the interbeds. Perched water samples were chemically analyzed and the results suggest that the water is due to lateral movement on the interbeds from the adjacent spreading areas of the Big Lost River.

The 1987 annual report, Laney et.al. (1988), continued the same objectives as the previous report and noted that analysis of data from the soil moisture measuring probes was initiated. The measured hydraulic gradients show that during much of the year there is downward flow through the unsaturated zone. Five computer codes were obtained and installed on the Cray computer. These are SEMTRA, FENTRA, TRACR3D, MAGNUM and CHAINT. Sampling of ambient air, and soil gases was conducted to determine the identity, location and relative concentration of selected chlorinated and aromatic volatile organic compounds. These measurements show that carbon tetrachioride, trichloroethane, trichloroethylene and tetrachloroethylene have migrated from several of the disposal pits. The results show a slight dowrward migration of background radionuclides from the weathering of the surficial sediments, migration of radionuclides from the buried waste within the sedimentary cover of the RWMC and downward migration of radionuclides from the buried waste into the 110 foot interbed and 


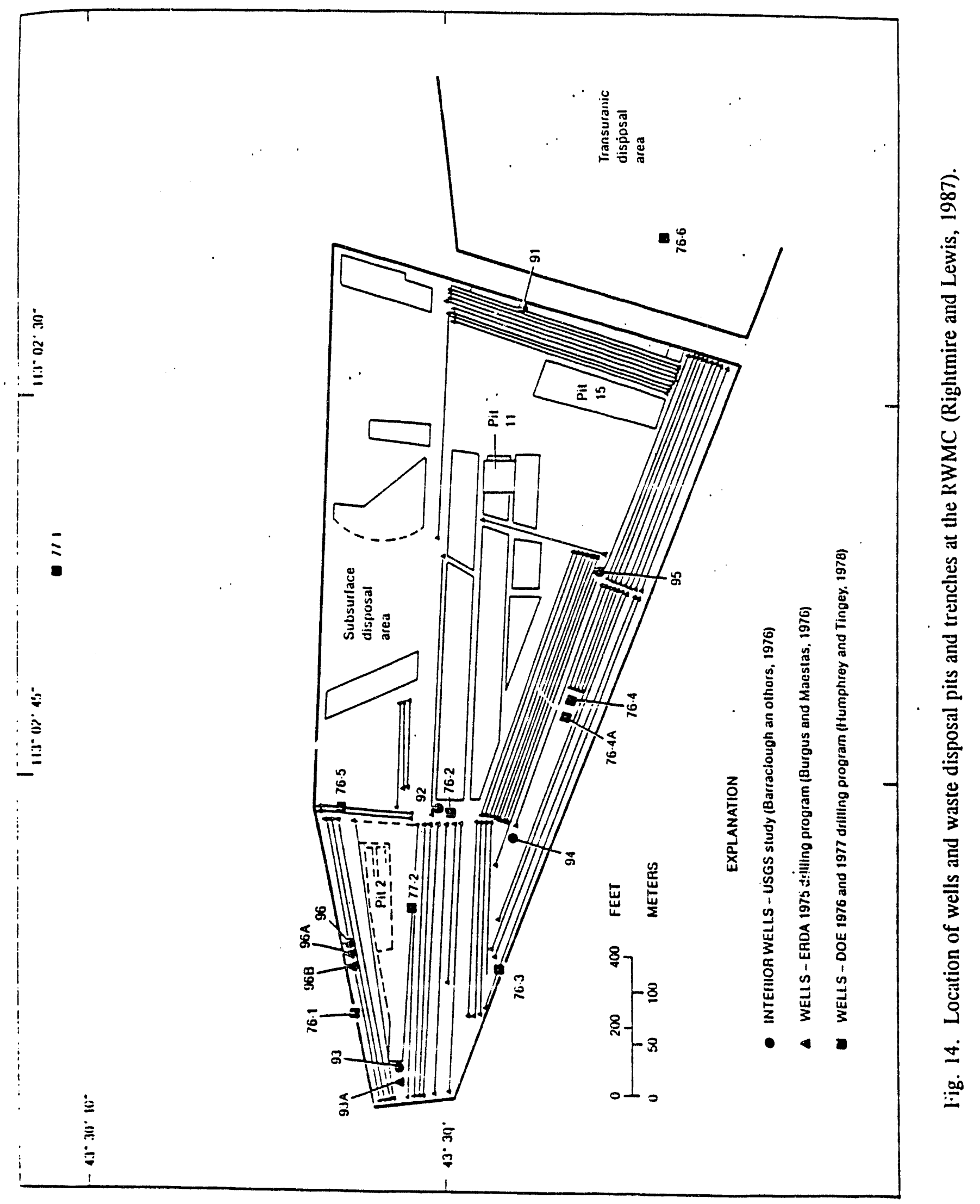


possibly into the 240 foot interbed.

Pittman (1989) reported the collection of hydrological and meteorological data for the unsaturated zone near the RWMC. The data are being collected to field calibrate a mathematical model to predict the long-term migration of radionuclides in the unsaturated zone. Two test trenches were installed in the surficial sediment adjacent to the RWMC to collect hydrologic data from undisturbed and disturbed soil. Hydrologic data collected during 1985 and 1986 includes measurements, taken every 12 hours, of soil temperature, soil-water potential from 30 sensors placed at selected depths to about 6 meters using thermocouple psychrometers; and soil moisture content measurements collected weekly in 9 neutron-probe access holes with a neutron moisture depth gage. Meteorological data are averaged every 6 hours and include wind speed, wind direction, relative humidity, air temperature; solar radiation and precipitation are totaled over the 6-hour period. Construction and instrumentation of the test trenches also is presented.

Tensiometers also were installed but soil conditions were too dry for them to work. The location of the test trench area relative to the RWMC is shown in Fig 15. A schematic of the west test trench is shown in Fig 16.

Anderson and Lewis (1989) present the stratigraphy of the unsaturated zone at the RWMC, describing in detail the characteristics of each basalt flow unit and sedimentary interbed.

Walton et.al. (1989) described a modeling study at the RWMC that was to develop an understanding of the flow and transport at the site. The modeling results provide qualitative agreement with monitoring data from the site suggesting that fracture flow in the basalt is an important component of the flow system.

Davis and Pittman (1990) present hydrological, meteorological, and geohydrological data collected during 1989 from the installed test trench described by Pittman (1989). Hydrological data collected from both disturbed and undisturbed soil include measurements of soil temperature and soil-water potential from 28 thermocouple psychrometers recorded hourly and averaged every 12 hours. Soil-moisture content measurements are collected biweekly in nine neutron-probe access holes. One additional neutronprobe access hole was installed in November 1987 to extend the area of coverage. Meteorological data coliected hourly and summarized daily included incoming and emitted long-wave radiation; incoming and reflected short-wave radiation; air temperature, relative humidity, and windspeed at 1 and $2 \mathrm{~m}$ above land surface; wind direstion; and precipitation. Samples of surficial sediment were collecter and used to describe grain-size distribution with depth and other physical characteristics.

Hubbell et al (1990) reported on the sampling and analysis plan for a field infiitration test of 


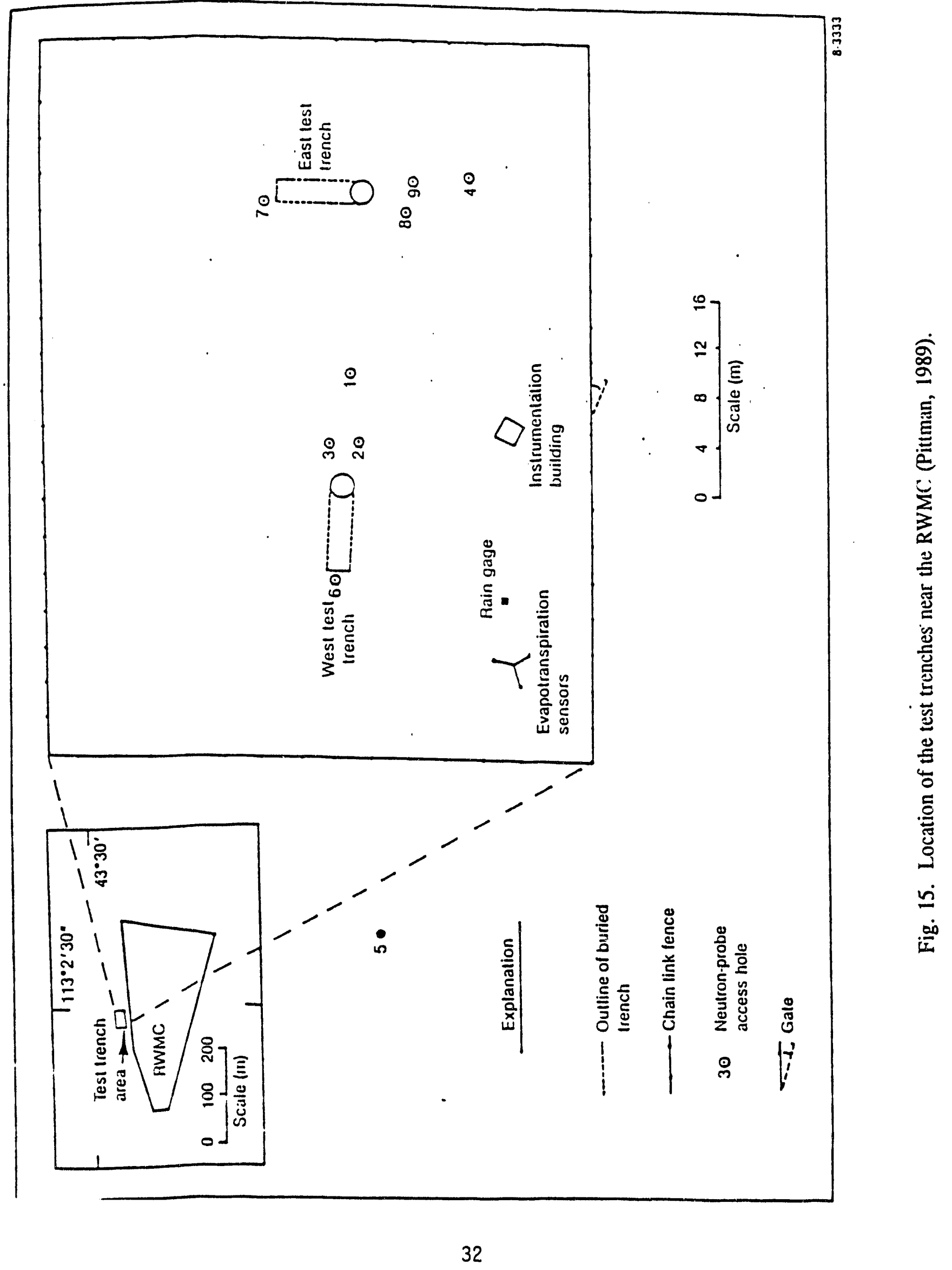




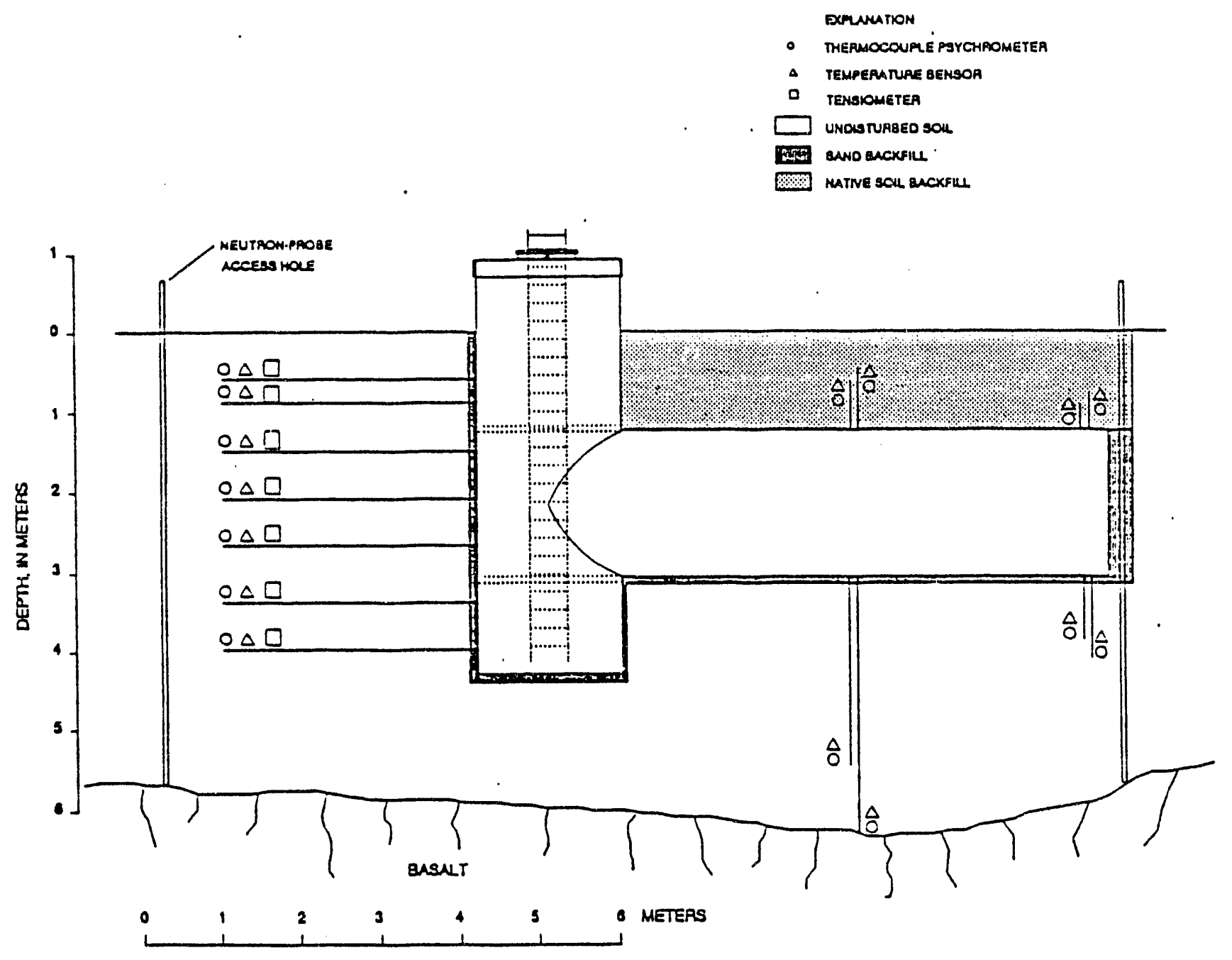

Fig. 16. Cross-section of west test trench. 
surficial sediments at the RWMC. The objective of the study is to estimate the unsaturated hydraulic conductivity of the surficial sediments at the USGS test trench site. The hydraulic properties are to be described using the van Genuchten functions. The experiment include infiltration, drainage and evaporation phases. Thermocouple psychrometers, tensiometers and neutron probe access holes are to be used to monitor soil moisture and tension.

Baca et.al. (1992) reported on a modeling study conducted at the RWMC with the purposes of determining 1) a relationship between meteorological conditions and net infiltration, 2) water movement associated with past flood events and 3) water travel times through the vadose zone. Simulations involved the use of the programs UNSAT-H, PORFLOW and FLOWMC. Simulations of infiltration were performed by modeling the processes of precipitation, evaporation, infiltration and soil-moisture redistribution. Both the natural sediments and the trench cover materials were used in the simulation. Simulation of the 1969 flooding event shows that the event may have moved a significant amount of water to the 110 foot interbed within a month. Travel times for infiltration during usual hydrologic conditions show a mean travel time of 610 years.

\section{SUMMARY}

During the early years of the INEL, the USGS conducted extensive studies (sitewide drilling program) of the geology and hydrology of the area collecting varied data over the years. The unsaturated zone has not received much attention until recently. The studies that have been done are a result of problems or concerns arising from liquid radioactive waste disposal. The TRA facility has the most information published about its waste disposal activities. The ICPP has less data about the unsaturated zone due to the fact that most waste water disposal has been to a well. Little is known about the effect of waste water disposal at the NRF on the unsaturated zone. Essentially no information was found about waste disposal activities at other facilities, primarily because there does not appear to be any reported problems associated with waste water disposal at these locations. The RWMC has received much attention in the last few years as the result of being priority No. 1 in the superfund clean up of the INEL. A considerable amount of data are available describing the unsaturated zone at the RWMC. These data have been collected to field calibrate a radionuclide migration model for the RWMC. 


\section{REFERENCES}

Adamic, M. L., J. R. Burr and G. J. McManus. 1984. Baseline Levels of Controlled Pollutants in the Vicinity of ICPP Processes. WINCO-1018.

Anderson, S. R. and B. D. Lewis. 1989. Stratigraphy of the Unsaturated Zone at the Radioactive Waste Management Complex, Idaho National Engineering Laboratory, Idaho. DOE/ID-22080, 53 p.

Ansley, 1990. Technical Work Plan for the Hydrogeologic Characterization of CFA Landfills II and III. INEL. U.S. Department of Energy.

1990. Sampling and Analysis Plan/Quality Assurance Project Plan for Groundwater Sampling at CFA Landfills II and III. INEL. U.S. Department of Energy.

Baca, R. G., S.O. Magnuson, H.D. Nguyen, and P. Martian. 1992. A Modeling Study of Water Flow in the Vadose Zone Beneath the RWMC. INEL. Department of Energy.

Barraclough, J. T., B. D. Lewis and R. G. Jensen. 1981. Hydrologic Conditions at the Idaho National Engineering Laboratory, Idaho, Emphasis 1974 to 1978. IDO-22060, 77 p.

Barraclough, J. T. and R. G. Jensen. 1976. Hydrologic Data for the Idaho National Engineering Laboratory Site, Idaho, 1971 to 1973 . IDO-22056, $52 \mathrm{p}$.

Barraclough, J. T., J. B. Robertson and V. J. Jones. 1976. Hydrology of the Solid Waste Burial Ground, as Related to the Potential Migration of Radionuclides, Idaho National Engineering Laboratory. IDO-22056, $183 \mathrm{p}$.

Barraclough, J. T., W. E. Teasdale, J. B. Robertson, and R. G. Jensen. 1967. Hydrology of the National Reactor Testing Station, Idaho, 1966. IDO-22049, 95 p.

Barraclough, J. T., W. E. Teasdale, and R. G. Jensen. 1966. Hydrology of the National Reactor Testing Station, Idaho: Annual Progress Report 1965. IDO-22048, 107 p.

Bartholomay, R. C. 1990. Mineralogy, Petrology and Grain Size of Surficial Sediment from the Big Lost River, Little Lost River and Birch Creek Drainages; Idaho National Engineering Laboratory, Idaho. M.S. Thesis, Idaho State University.

Burgas, W. H. and S. E. Maestas. 1976. The 1975 Radioactive Waste Management Complex Core Drilling Program, a further investigation of subsurface radioactivity at the RWMC, Idaho National Engineering Laboratory. US Energy, IDO-10065, 36 p.

Davis, L. C. and J. R. Pittman. 1990. Hydrological, Meteorological, and Geohydrological Data for an Unsaturated Zone Study near the Radioactive Waste Managernent Complex, Idaho National Engineering Laboratory, Idaho, 1987. DOE/ID-22086, 208 p.

Echo, John and D. B. Hawkins. 1966. Algae Influence on Radionuclides in Settling Ponds. Nature. Vol 209. No. 5028, p 1105-1107 
Hardy, C. E. and J. H. Browder. 1985. Conceptual Design Report for the TRA Radioactive Liquid Waste Cleanup Systems Phase III. Internal Technical Report. EG\&G Idaho, Inc.

INEL Site Environmental Surveillance Data for the First Quarter 1991. Environmental Science Branch, Radiological and Environmental Science Laboratory. U.S. Department of Energy.

Hawkins, D. B. and H. L. Short. 1965. Equations for the Sorption of Cesium and Strontium on Soil and Clinoptilolite. IDO-12046, 133 p.

Hubbel, J. M., J. F. Kaminsky and J. B. Sisson. 1990. Sampling and Analysis Plan for the Field Infiltration Test of Surficial Sediments at the Radioactive Waste Manages rent Complex Idaho National Engineering Laboratory, Idaho. EG\&G Inc. EGG-WM-9159, 43 p.

Hubbell, J. M., L.C. Hull, T.G.H. Humphrey, B.F. Russell, J.R. Pittman and K.M. Cannon. 1985. Subsurface Investigations Program at the Radioactive Waste Management Complex of the Idaho National Engineering Laboratory. U.S. Department of Energy.

Hubbell, J. M., L. C. Hull, T.G.H. Humphrey, B.F. Russell, J.R. Pittman and P.R. Fischer. 1987. Subsurface Investigations Program at the Radioactive Waste Management Complex of the INEL. U.S. Department of Energy.

Hull, L. C. 1987. Hydrogeologic Assessment of Land Disposal Unit, CPP-37 ICPP Gravel Pit \#2. EG\&G Idaho, Inc., Idaho National Engineering Laboratory, 46 p.

Humphrey, T. G. and F. H. Tingey. 1978. The Subsurface Migration of Radionuclides at the Radioactive Waste Management Complex; 1976-1977. US DOE, IDO publication TREE-1171, $98 \mathrm{p}$.

Jones, P. H. 1961. Hydrology of Waste Disposal National Reactor Testing Station, Idaho: An Interim Report. IDO-22042, 82 p.

Laney, P. T., S. C. Minkin, R. G. Baca, D. H. McElroy, J. M. Hubbell, L. C. Hull, B. F. Russell, G.D. Stormberg and J. T. Pittman. 1988. Subsurface Investigations Program at the RWMC of the INEL. Departmient of Energ $y$.

Lewis, B. D., J. M. Eagleton and R. G. Jensen. 1985. Aqueous Radoactive- and Industrial- Waste Disposal at the Idaho National Engineering Laboratory Through 1982. DOE/ID-22069, 13 p.

Lewis. B. D. and R. G. Jensen. 1984. Hydrologic Conditions at the Idaho National Engineering Laboratery, Idaho: 1979-1981 Update. IDO-22066, 65 p.

Lewis, B. D. and F. J. Goldstein. 1982. Evaluation of a Predictive Ground-Water Solute-Transport Model at the Idaho National Engineering Laboratory, Idaho. IDO-22062, 71 p.

Mann, L. J. and L. D. Cecil. 1990. Tritium in Ground Water at the Idaho National Engineering Laboratory, Idaho. DOE/ID-22090, 35 p. 
Morris, D. A., J. T. Barraclough, G. H. Chase, W. E. Teasdale, and R. G. Jensen. 1965. Hydrology of Subsurface Waste Disposal, National Reactor Testing Station, Idaho: Annual Progress Report 1964. IDO-22047, $125 \mathrm{p}$.

Morris, D. A., W. E. Teasdale and Others. 1964. Hydrology of Subsurface Waste Disposal National Reactor Testing Station, Idaho: Annual Progress Report 1963. IDO-22046, 96 p.

Morris, D. A. and Others. 1963. Hydrology of Waste Disposal, National Reactor Testing Station, Idaho: Annual Progress Report 1962. IDO-22044, 99 p.

Nace, R. L., Morris Deutsch and P. T. Voegeli. 1956a. Geography, Geology, and Water Resources of the National Reactor Testing Station, Idaho: Part 2. Geography and Geology. IDO-22033. $225 \mathrm{p}$.

Nace, R. L., Morris Deutsch and P. T. Voegeli. 1956b. Geography, Geology, and Water Resources of the National Reactor Testing Station, Idaho: Appendix 1. Basic Data on the Geography and Geology. IDO-22033. $53 \mathrm{p}$.

Nace, R. L., J. W. Stewart, W. C. Walton and Others. 1959. Geography, Geology and Water Resources of the National Reactor Testing Station, Idaho; Part 3. IDO-22034, 253 p.

RNace, R. L., P. T. Voegeli, Morris Deutsch. Geology, Hydrology and Waste Management of the National Reactor Testing Station, Idaho. USGS Professional Paper 725-B.

Nace, R. L., Morris Deutsch, P. T. Voegeli. 1973. Physical Environment of the National Reactor Testing Station -- A Summary. USGS Water Supply Paper 725-A.

Olmsted, F. H. 1962. Chemical and Physical Character of Ground Water in the National Reactor Testing Station, Idaho. IDO-22043, $81 \mathrm{p}$.

Ousley, S. L., L. C. Hull, and S. M. Burns. 1988. Shallow Drilling Report for CFA Landfills II and III FY 1988. INEL. U.S. DOE.

Peckham, A. E. 1959. Investigations of Underground Waste Disposal, Chemical Processing Plant, National Reactor Testing Station, Idaho. IDO-22039, 35 p.

Pittman, J. R. 1989. Hydrological and Meteorological Data for an Unsaturated Zone Study Near the Radioactive Waste Management Complex, Idaho National Engineering Laboratory, Idaho, 1985 to 1986 . DOE/ID-22079, $160 \mathrm{p}$.

Pittman, J. R., R. G. Jensen and Patrick R. Fischer. 1988. Hydrologic Conditions at the Idaho National Engineering Laboratory 1982 to 1985 . DOE/ID-22078, 73 p.

Rightmire, C. T. and B. D. Lewis. 1987. Hydrogeology and Geochemistry of the Unsaturated Zone, Radioactive Waste Management Complex, Idaho National Engineering Laboratory, Idaho. DOE/ID-22073, 89 p. 
Rightmire, C. T. and B. D. Lewis. 1987. Geologic Data Collected and Analytical Procedures Used during a Geochemical Investigation of the Unsaturated Zone, Radioactive Waste Management Complex, Idaho National Engineering Laboratory, Idaho. DOE/ID-22072, 83 p.

Rightmire, C. T. 1984. Description and Hydrological Implications of Cored Sedimentary Material From the 1975 Drilling Program and the Radioactive Waste Management Complex, Idaho. DOE/ID22067.

Robertson, J. B. 1977. Numerical Modeling of Subsurface Radioactive Solute Transport from WasteSeepage Ponds at the Idaho National Engineering Laboratory. IDO-22057, 68 p.

Robertson, J. B. 1974. Digital Modeling of Radioactive and Chemical Waste Transport in the Snake River Plain Aquifer at the National Reactor Testing Station, Idaho. IDO-22054, $41 \mathrm{p}$.

Robertson, J. B., Robert Shoen and J. T. Barraclough. 1974. The Influence of Liquid Waste Disposal on the Geochemistry of Water at the National Reactor Testing Station, Idaho, 1952-1970. IDO22053,210 p.

Schmalz, B. L. 1972. Radionuclide Distribution in Soil Mantle of the Lithosphere as a Consequence of Waste Disposal at the National Reactor Testing Station. IDO-10049.

Schmalz, B. L. 1968. Liquid Waste at the National Reactor Testing Station, Idaho. IDO-12066, 125 p.

Schmalz, B. L. and W. L. Polzer. 1969. Tritiated Water Distribution in Unsaturated Soil. Soil Science, 108, pp 43-47.

Schmalz, B. L. 1959. Interim Report of Liquid Waste Disposal in the Vicinity of the Idaho Chemical Processing Plant, National Reactor Testing Station, Idaho. U.S. Atomic Energy Commission, Idaho Operations Office. $23 \mathrm{p}$.

Stewart, J. W., R. L. Nace, K. H. Fowler, A. E. Peckham and P. T. Voegeli. 1960. Geography, Geology and Water Resources of the National Reactor Testing Station, Idaho; Appendix 2 -Basic Hydrologic Data. U.S. Geological Survey. 247 p.

Thomas, T. R. 1988. Modeling Hypothetical Groundwater Transport of Nitrates Chromium and Cadmium at the Idaho Chemical Processing Plant. Westinghouse Idaho Nuclear Co. Inc. Department of Energy.

1988. TAN Background Soil Sampling Plan. INEL. Department of Energy.

Van Deusen, L. C., D. R. Monrot, L. C. Hu!l, K. D. Davis, F. H. Weiler, and D. E. Sheldon. 1988. Corrective Action Investigation of a Mixed Waste Contaminated Percolation Pond. U.S. Department of Energy, Idaho Operations Office.

Walton, J. C., R. G. Baca, and T. L. Rasmussen. 1989. Flow and Transport of Radionuclides in Unsaturated Fractured Basalt. Proceedings of the Symposium on Waste Management. University of Arizonz. Tucsen. Arizonz. 
Wang, J. S. Y. and T. N. Narasimhan. 1985. Hydrologic Mechanisms Governing Fluid Flow in a Partially Saturated Porous Medium. Water Resources Research, 21, 12, pp. 1861-1874. 


\section{Physical Constants of Interest}

\begin{tabular}{ll} 
Radio Isotope & Half-Life \\
\hline Tritium & $7.2 \mathrm{yr}$ \\
Strontium-90 & $28 \mathrm{yr}$ \\
Iodine-131 & 8.14 days \\
Cesium-137 & $33 \mathrm{yr}$ \\
Zirconium-95 & 65 days \\
Niobium-95 & 35 days
\end{tabular}

99 percent of the radio isotope will decay within 7.2 half-lives. 


\title{
REVIEW OF SURFACE WATER HYDROLOGY AND RECHARGE TO GROUND WATER
}

\author{
Dennis Horn \\ John Finnie
}

Introduction

Activities during this first year have primarily been. concentrated on a detailed review of previously published documents, studies, and data pertinent to the description of surface water hydrology and ground water recharge within or near the INEL site. Abstracts of these documents are included elsewhere in this report, and have been placed in the data base system developed for the project. The purpose of this section of the final report is to briefly review the site hydrology, discuss the major data deficiencies disclosed during the study, and to present recommendations for future work.

Summary of INEL Hydrology

In 1949, the USGS was requested to study the water resources at the INEL, then called the NRTS, by the Atomic Energy Commission. Initially they studied the hydrology before operations began, and then in 1952 they began investigating the effects of reactor operations on the water resources as well as natural changes to the environment. This study has been continued through the years, and a summary is presented here. Tritium is the primary contaminant discussed because it has migrated much more than any other and thus is the primary concern.

The groundv:ater table lies $200 \mathrm{ft}$ to $1000 \mathrm{ft}$ beneath the INEL, and flows to the south-southwest at 5 to $20 \mathrm{ft} / \mathrm{d}$; transmissivity ranges from 134,000 to $13,400,000$ cubic feet per day. The average gradient under the site is 4 feet per mile, although this varies around the site depending on recharge. Basalt with interbedded sediment is the main rock unit that make up the aquifer.

\section{Period of 1971-1973:}

Discharge on the Big Lost River for this period was just slightly above average, which, for 57 years, was $21 \%, 000$ acre feet. The respective flows were:

$1971=311,500$ acre feet
$1972=267,300$ acre feet
$1973=205,300$ acre feet 
The flow for 1971 was the fourth highest discharge on record for the 57 years. Recharge from the various drainages caused the water table to rise to record highs in some places, with the flows in 1971 causing the largest fluctuations.

A strontium-90 waste plume covered approximately 1.5 square miles at this time. Since the plume was so small, it was assumed that strontium-90 was being sorbed from solution as it moved through the aquifer. A tritium plume covered 15 square miles in the aquifer, and extended about 5 miles downgradient from the point of disposal.

Period of 1974-1978:

Streamflow for this period of time was rather large for the first two years, then dropped down to average and below. The 62 year average was 214,700 acre feet, and the respective flows are given below.

$$
\begin{aligned}
& 1974=319,900 \text { acre feet } \\
& 1975=317,100 \text { acre feet } \\
& 1976=263,600 \text { acre feet } \\
& 1977=160,300 \text { acre feet } \\
& 1978=225,900 \text { acre feet }
\end{aligned}
$$

The flows for 1974 and 1975 were fourth and fifth highest on record, respectively. Despite these high early flows, the water table dropped a net of $0.2^{\prime}$ in the north and $10^{\prime}$ in the central and southern parts of the site. The perched water tables near the Big Lost River saw large fluctuations due to high and low flows on the river. As before, any large recharge events were only seen locally.

The tritium waste plume continued to move through the aquifer, growing to 28 square miles, with a distance of 7.5 miles from the point of discharge. The strontium-90 plume was approximately 2.2 square miles in size.

\section{Period of 1979-1981:}

Streamflow was low for these years, with flows just above and below average. Average for the 64 years of record was 215,000 acre feet, and flows for this period are given below.

$$
\begin{aligned}
& 1979=202,400 \text { acre feet } \\
& 1980=249.500 \text { acre feet }
\end{aligned}
$$


$1981=240,100$ acre feet

Since 1977 , very little or no water has flowed past the INEL diversion gaging station. With flows being so low, the local water table dropped. In the north, it dropped $2 \mathrm{ft}$, and in areas sensitive to the Big Lost River, drops were about $10 \mathrm{ft}$.

The amount of waste discharged to the TRA ponds continued to decrease, to about 116 million gallons per year. The plumes continued to grow despite this drop is discharge. Tritium was now distributed over 42 square miles in the Snake River Plain aquifer, and was found 8 miles from discharge points. The strontium-90 waste plume covered an area approximately 2.1 square miles. Other, much smaller plumes existed, but their size and movement did not compare to that of tritium.

Period of 1982-1985:

During this period, extensive water level measurements were taken, both of perched water tables and the regional aquifer. Water samples were taken of the groundwater to determine the chemical quality of the water entering and leaving the site, and surface water samples were taken at known recharge areas. An event that had a large effect on the aquifer occurred at the ICPP. The disposal well that had been used since operations began was abandoned in 1984, and ponds were placed into operation. This caused the concentration of tritium in perched groundwater underlying the ponds to increase, but the concentration in the Snake River Plain aquifer to decrease because it was no longer being injected directly. Tritium was detected in the groundwater near the southern boundary on INEL, nine miles south of the ICPP and TRA.

Recharge to the aquifer during high flow years on the Big Lost River is significant, as was seen during this period. The year 1984 was the highest flow on record, with 1983 fourth and 1982 sixth. The flows for this period are given below.

$$
\begin{aligned}
& 1982=328,000 \text { acre-feet } \\
& 1983=372,000 \text { acre-feet } \\
& 1984=476,000 \text { acre-feet } \\
& 1985=262,000 \text { acre-feet }
\end{aligned}
$$

The average flow over the 69 years of record is 227,500 acre-reet. Water level changes were very 
noticeable during these wet years. In the north, which is affected by Birch Creek and Mud Lake, the groundwater rose $3 \mathrm{ft}$; near the Big Lost River, rises were between $6 \mathrm{ft}$. and $12 \mathrm{ft}$; near the RWMC, levels rose $16 \mathrm{ft}$. in response to recharge from surface water diverted from the Big Lost River to the spreading areas. Although these rises seem large, they were primarily on a local basis because recharge has only large local effects.

Perched water tables continued to grow under ponds at the TRA and ICPP, primarily influenced by recharge and method of disposal changes from disposal wells to ponds. The amount of total waste disposed to all ponds at the TRA did decrease during this time. Tritium is the only radionuclide that has been found to migrate large distances from points of disposal. In October 1985, tritium was distributed in the Snake River Plain aquifer over about 51 square miles, and had migrated as much as 9.1 miles downgradient from discharge points. The strontium-90 plume covered an area of the aquifer of about 2 square miles. Other contaminants have been found in the aquifer, but they are either in minute concentrations or have migrated very small distances from points of disposal.

Period of 1986-1988:

Flow in the Big Lost River was low for this period of time, with only one year exceeding the average. The 72-year average was 227,500 AF, and the discharges, as measured below Mackay Reservoir, were:

$$
\begin{aligned}
& 1986=326,500 \mathrm{AF} \\
& 1987=175,000 \mathrm{AF} \text { (not given specifically) } \\
& 1988=141,300 \mathrm{AF}
\end{aligned}
$$

Groundwater levels reflected this dramatic drop in flow, as wells near the RWMC had a net drop of $26.8 \mathrm{ft}$ and near the TAN the water only rose $4.3 \mathrm{ft}$.

The tritium plume shrank from a size of 51 square miles to 45 square miles as a result of reduced discharges, decay, and dilution. The strontium-90 plume decreased from 2 to 0.8 square miles, primarily due to the diversion of liquid waste disposal from a disposal well to infiltration ponds. 


\section{Identified Data Deficiencies}

There have been numerous studies performed during the past 40 years on site hydrology, and the data that have been collected are voluminous. Nevertheless, a careful review of this material indicates that there are still areas of concern that should be addressed during future years, through additional data collection or monitoring. These concerns, representing perceived data deficiencies, are summarized below:

Streamflow data

Although the USGS has done an excellent job in collecting and publishing flow data for the Big Lost River, the information available for locations between the gage at Arco and the INEL playas is insufficient for the types of detailed recharge or flood studies that may be desirable. There are several reasons for these data deficiencies: 1) the gages have been operated intermittently, with no apparent long-term commitment to keeping them in place and operational; 2) the periods of actual operation have included drought years, when there has been no flow to record; and 3) some of the recorded data have been unpublished because of USGS concerns with their accuracy.

For future studies of ground water recharge along the Big Lost River channel system and beneath the spreading basins, it would be desirable to have flow gages continually operated at several key locations: at the site boundary; at and immediately downstream of the diversion structure; and at one or two locations between the diversion structure and the playas.

Recharge Data

Bennett's study (1990) of recharge from the Big Lost River is the only definitive estimate of reach-byreach channel recharge available at this time. It was based on a limited amount of data in monthly time intervals, covering a relatively short historical period. Much of the data used remains unpublished by the USGS, because of their judgement that the recorded data did not conform to their quality assurance program. 
Provided that good quality daily flow data could be obtained for future years at multiple locations, it is probable that more accurate and detailed flow/recharge relationships could be eventually developed.

Similarly, recharge data are lacking for the INEL spreading basins. During large flow events, these basins would receive much of the discharge from the river and would become the primary source of recharge. To evaluate recharge behavior during their use, it would be necessary to have both inflow data (measured at the diversion structure), and continuous water level records at the spreading basins. There are no such water level recorders installed at this time, although non-recording staff gages are apparently present at the spreading basin sites.

Topographic Data

Because of the flat land surface present throughout much of the INEL site, existing topographic information is inadequate for accurate studies of flood hazards or of the operation of the spreading basins. Although it would be prohibitively expensive to obtain detailed topographic maps of the entire site, selected areas of concern could be mapped at a lower cost. The recommendation for a future flood hazard study (discussed later) includes the preparation of a cost estimate to obtain the necessary detailed topographic maps for these areas. 
Bibliography of Key Documents Related to Site Hydrology

The following bibliography contains a listing of those documents that have been judged to be especially pertinent to the description or study of surface water hydrology and recharge to ground water. These, along with other less relevant reports, have been abstracted and included in the data base of report abstracts.

\section{DOCUMENTS REVIEWED AND PHOTOCOPIED}

Barraclough, J.T., Lewis, B.D., and Jensen, R.G., 1981, Hydrologic conditions at the INEL, Idaho, 1974 to 1978: IDO - 22060 .

Barraclough, J.T. and Jensen, R.G., 1976, Hydrologic data for the INEL site, Idaho, 1971 to 1973: IDO 22055.

Barraclough, J.T., Robertson, J.B., Janzer, V.J., and Saindon, L.G., 1976, Hydrology of the solid waste burial ground, as related to the potential migration of radionuclides, INEL: IDO -22056.

Barraclough, J.T., Teasdale, W.E. and Jensen, R.G., 1967, Hydrology of the NRTS, Idaho, annual progress report 1965: IDO - 22048.

Barraclough, J.T., Teasdale, W.E., Robertson, J.B., and Jensen, R.G., 1966, Hydrology of the NRTS, Idaho: IDO - 22049.

Bartholomay, R.C., 1990, Mineralogical correlation of surficial sediment from area drainages with selected sedimentary interbeds at the INEL, Idaho: DOE/ID - 22092.

Bartholomay, R.C., Knobel, L.L., and Davis, L.C., 1989, Mineralogy and grain size of surficial sediment from the Big Lost River drainage and vicinity, with chemical and physical characteristics of geologic materials from selected sites at the INEL, Idaho: DOE/ID - 22081.

Bennett, C.M., 1990, Streamflow losses and groundwater level changes along the Big Lost River at the INEL, Idaho: DOE/ID - 22091.

Bennett, C.M., 1986, Capacity of the diversion channel below the flood-control dam on the Big Lost River at the INEL, Idaho: IDO - 22071.

Bowman, A.L., Downs, W.F., Moor, K.S., and Russell, B.F., INEL Environmental characterization report Volume I: Summary: EGG-NPR-6688.

Bowman, A.L., Downs, W.F., Moor, K.S., and Russeil, B.F., INEL Environmental characterization report Volume III: Appendices C, E-H: EGG-NPR-6688.

Carrigan, P.H. Jr., 1972, Probability of exceeding capacity of flood-control system at the NRTS, Idaho: IDO $-22052$. 
Deutsch, M., Nace, R.L. and Voegeli, P.T., 1952, Geology, groundwater, and waste disposal at the Aircraft Nuclear Propulsion Project Site, NRTS, Idaho: IDO - 22023.

Deutsch, M., Nace, R.L., and Shuter, E., 1954, Geology and groundwater resources of a part of Wester $\mathrm{n}$ Jefferson County adjacent to the NRTS, Idaho: IDO - 22028.

Druffel, L., Stiltner, G.J. and Keefer, T.N., 1979, Probable hydrologic effects of a hypothetical failure of Mackay Dam on the Big Lost River valley from Mackay, Idaho, to the INEL: IDO - 22058.

Garabedian, S.P., 1989, Hydrology and digital simulation of the regional aquifer system, eastern Snake River Plain, Idaho: USGS Open File Report 87-237.

Goldstein, F.J. and Weight, W.D., 1982, Subsurface information from 8 wells drilled at the INEL, southeastern Idaho: IDO - 22063.

Hull, L.C., 1990, Hydrologic assessment of Land Disposal Unit, CPP-37, ICPP Gravel Pit \#2: EG\&G, Inc., Hydrology Unit, INEL.

Jones, P.H., 1961, Hydrology of waste disposal, NRTS, Idaho: IDO - 22042.

Lamke, R.D., 1969, Stage-Discharge relations on Big Lost River within NRTS, Idaho: IDO 22050.

Lewis, B.D., and Goldstein, F.J., 1982, Evaluation of a predictive groundwater solute transport model at the INEL, Idaho: IDO - 22062.

Lewis, B.D. and Jensen, R.G., 1984, Hydrologic conditions at the INEL, Idaho: 1979-1981 update: IDO 22066.

Mann, L.J., Chew, E.W., Morton, J.S., and Randolph, R.B., Iodine-129 in the Snake River Plain aquifer at the INEL, Idaho: DOE/ID - 22076.

Morris, D.A., 1963, Hydrology of waste disposal, NRTS, Idaho, annual progress report 1962: IDO 22044.

Morris, D.A., Barraclough, J.T., Chase, G.H., Teasdale, W.E. and Jensen, R.G., Hydrology of subsurface waste disposal, NRTS, Idaho, Annual Progress Report 1964: IDO - 22047.

Morris, D.A., Teasdale, W.E. and others, 1964, Hydrology of subsurface waste disposal, NRTS, Idaho, annual progress report 1963: IDO - 22046.

Nace, R.L., and Barraclough, J.T., 1952, Groundwater recharge from the Big Lost River below Arco, Idaho: IDO - 22016.

Olmsted, F.H., 1962, Chemical and physical character of groundwater in the NRTS, Idaho: IDO 22043.

Orr, B., and Cecil, L.D., Hydrologic conditions and distribution of selected chemical constituents in water, 
Snake River Plain aquifer, INEL, Idaho, 1986-1988: DOE/ID -22096.

Peckham, A.E., 1959, Investigation of underground waste disposal, Chemical Processing Plant area, NRTS, Idaho: IDO - 22039.

Pittman, J.R., Jensen, R.G., and Fisher, P.R., 1988, Hydrologic conditions at the INEL, 1982 to 1985: IDO - 22078.

Robertson, J.B., 1974, Digital modeling of radioactive and chemical waste transport in the Snake River Plain aquifer at the NRTS, Idaho: IDO - 22054.

Robertson, J.B., 1977, Numerical modeling of subsurface radioactive solute transport from waste-see page ponds at the INEL: IDO - 22057.

Robertson, J.B., Schoen, R. and Barraclough, J.T., 1974, The influence of liquid waste disposal on the geochemistry of water at the NRTS, Idaho, 1952-1970: IDO - 22053.

Stewart, J.W., 1951, Results of tests on wells at Sites 3 and 7, NRTS, Idaho: IDO - 22011.

Wood, T.R., 1990, Impact of surface water recharge on the design of a groundwater monitoring system for the RWMC, INEL: EGG-M-9012. 
Recommendations for Future Work

During the initial year of the project, the review of prior studies indicate that there are several specific topic areas where further research or engineering studies are needed, and can be performed using existing data. A brief summary of three proposed studies is provided below, with more detailed descriptions of each study included as attachments to this report.

An Investigation of Seepage Rates and Groundwater Response to Recharge Along the Big Lost River (Attachment \#1)

This study, already begun by Erik Coats (graduate student), will examine the daily seepage rates from the Big Lost River as it flows from Arco to the INEL playas. Its goal is to develop reach-by-reach seepage estimates as functions of streamflow in the channel system, and to relate the daily recharge rates to observed changes in groundwater elevations in wells near the Big Lost River Channel. Results from this study should be available during the summer of 1992 .

Surface Water and Ground Water Interactions at the Spreading Basins of the Big Lost River (Attachment \#2)

This study, proposed as part of the work effort during the second year of the project, will examine the movement of surface water through the unsaturated zone beneath the spreading basins to the water table. Using a computer model of the unsaturated flow process, the research will focus on the time required for the ground water to respond to surface water inputs to the spreading basins, and the extent of lateral migration of the ground water mound that results from this recharge. 
A Study of Flood Hazards for the INEL Site (Attachment \#3)

Although a number of prior studies have examined specific aspects of flood hazards at various locations within the INEL site, it is proposed that a comprehensive summary be prepared to describe more fully and accurately the extent of the site's flood hazard areas. This work would involve a combination of new engineering studies, an updating and upgrading of prior studies, and an integration of these studies into a single summary document. The proposal for this work, previously submitted to the INEL Oversight Program, is considered beyond the scope of the current project, and would require additional funding. 


\section{ATTACHMENT \#1}

\section{An Investigation of Seepage Rates and Ground Water Response \\ to Recharge along the Big Lost River \\ Dennis Horn and Erik Coats}

\section{Proposal Overview}

Purpose: The research will study seepage rates along the Big Lost River basin from Arco through the INEL to the playas where the river ends, and determine seepage functions for various reaches based on daily flows. In addition to finding seepage functions, the study will examine the effects of the recharge on the regional groundwater system, and develop a relationship between recharge and groundwater level changes. The years included in the study are $1965-1990$.

Problem: The Big Lost River flows intermittently from Arco to the playas; intermittently because depending on the magnitude of the flow in the river sometimes water will reach the playas and other times it sinks well in advance of the playas. This is due to the highly permeable alluvial deposits that line the channel. Due to the unpredictability of seepage, streamflow is very difficult to estimate in any reach. The intended research results will place some predictability on seepage by deriving a set of equations that can be used to estimate total losses.

\section{Infiltration Study}

In 1990, C.M. Bennett, then employed by the USGS, researched streamflow losses for this section of the river and wrote a report (Streamflow Losses and Ground Water Level Changes along the Big Lost River at the INEL, Idaho, DOE/ID - 22091) detailing his results. In this proposed research, a time period and reach similar to Bennett's will be examined, permitting the use of comparable subreaches and gage data. The research will differ from Bennett's in that he only looked at monthly streamflow losses, did not attempt 
to derive a seepage function for each reach, and did not examine in detail the interrelationship between the river and ground water.

To determine the seepage loss from the river, flows in reaches will be compared using streamflow gage data, and from these comparisons, infiltration can be calculated. Selecting the reaches to use in the research will be a problem, since Bennett used gages that are not published by the USGS and some data for USGS gages that also are not published. According to Bennett, the flow measurements in question were not taken under strict USGS QA standards. However, the USGS has agreed to supply much of this unpublished data for use in this proposed study. Once these have been obtained, the river will be subdivided into reaches based on stream gage locations. (published and unpublished)

\section{Ground Water Study}

For this part of the study, research will focus on what effect and how large an effect seepage from the river has on the water table and the time of lag between seepage and ground water rise. These relationships may only pertain to higher flows, as lower flows may not cause any significant changes in ground water levels. (the distinction between high and low flows will be defin ad as the study progresses.) To calculate loss effects, well logs will be compared against flows in the river. All well data can be obtained from either the USGS or the Department of Water Resources.

This study will be most important for the Radioactive Waste Management Complex (RWMC). It is located south and east of the river and contains buried transuranic waste. Anytime large flows in the river cause the ground water table to rise dramatically, there is concern it could impact the buried waste. This study, when completed, will allow them to determine when to be concerned. 


\section{Conclusion}

This study will prove to be very useful for the INEL. The INEL will be able to predict the amount of water expected to flow onto the site, how far along the river it could flow, to what extent the ground water will fluctuate and whether it is a concern. 


\author{
ATTACHMENT \#2 \\ Surface Water and Ground Water Interactions at \\ the Spreading Basins of the Big Lost River \\ John Finnie
}

Introduction

The spreading basins of the Big Lost River in the southwest corner of the Idaho National Engineering Laboratory (INEL) are one of the area's largest discrete recharge areas. A large ground water mound beneath the spreading basins has been identifiable following significant nun off events. Robertson [1974] modelled the groundwater at INEL and was able to reproduce this mound for 1964. His model considered only saturated flow and treated the spreading basins as a point source.

Objectives

It is the objective of this proposed research to model the unsaturated flow of recharge from the basins to the water table. The research would try to answer the following questions. What is a reasonable travel time from the basins to the water table? How fast does the ground water mound appear beneath the basins? Can recharge from the ponds travel laterally and affect ground water elevations at the Radioactive Waste Management Complex (RWMC)?

Method

The success of this research depends upon the quality of the geologic and hydrologic data and computer model. Since some data are not adequately known (i.e. thickness of basalt and interbeded layers, fracturing of basalt), the expected output of this research is an analysis of the sensitivity of the results (travel times and mound growth and dimensions) to assumed values of geologic and hydrologic data. 


\section{Hydrologic Data}

Among the most precise data to be used in this study is the flow in the Big Lost River and the height of ground water. These are available from the U.S. Geologic Survey (USGS). Other sources of data include the following. Lamke [1969] developed stage discharge relationships for the spreading basins. Bennett [1986] modelled the capacity of the diversion channel and reported dimensions of other channels connecting the four spreading basins. Carrigan [1972] routed flood flows into the spreading basins and reported elevation versus volume data, stage-discharge relationships, and functions that relate seepage losses to pool depths for the individual basins.

\section{Geologic characterization}

The spreading basins are surrounded on three sides by the following wells: $9,86,87,88,89,90$, and 109. The Big Lost River is located on the fourth side. Hydrologic sections (fence diagrams) that show layering of basalt and sediments are presented by Lewis and Goldstein [1982]. They also give ground water elevations for 1980. Knutson et al. [1992] characterized the thickness of individual basalt flow elements for the nearby RWMC. Rightmire and Lewis [1987] also give interbed layer thickness at the RWMC. Robertson [1974] presents aquifer transmissivities for the INEL which were found by calibration of a computer model. Baca et al. [1992] modelled unsaturated flow beneath the RWMC and presented characteristic and conductivity curves (van Genuchten parameters) for sediments and basalt at the RWMC.

\section{Computer model}

The computer model proposed for use in this research is FLASH [Baca 1992]. FLASH is capable of modelling two-dimensional (radial coordinates) unsaturated flow in porous media that is continuous with discrete fractures. Versions of FLASH are available for work stations or larger computers. Since the author has access to and experience with Cray supercomputers, the calculations will be performed on a 
supercomputer.

IV. Modeling procedure

Recent hydrologic data will be reviewed for periods with good river flow and ground water elevation data. The flood flow will be routed into the basins and seepage amounts calculated from Carrigan's [1972] seepage functions. A number of realistic combinations of basalt and sediment layers will be selected. The hydraulic parameters of Baca et al. [1992] will be applied to each strata. The flow of water from the spreading basins will be modelled and the calculated ground water mound will be compared to measured ground water elevations. The process will be repeated for each of the selected combinations. Only a limited number of combinations will result in the observed ground water mounding. This procedure will identify the most likely combinations of layers and will result in an improved hydraulic model of the spreading basins. Discrete fractures will also be added to basalt layers to determine their effect on travel times and well water elevations. 


\section{REFERENCES}

Baca, R.G. 1992. "A finite element computer code for variably-saturated flow in fractured porous media (in preparation), EG\&G Idaho, Inc. Idaho Falls, ID.

Baca, R.G., S.O. Magnuson, H.D. Nguyen, and P. Martian. 1992. "A modeling study of water flow in the vadose zone beneath the Radioactive Waste Management Complex", EGG-GEO-10068, EG\&G Idaho Inc, Idaho Falls, ID.

Bennett, C.M. 1986. "Capacity of the diversion channel below the flood control dam on the Big Lost River at Idaho National Engineering Laboratory." U.S. Geological Survey, Water-Resources Investigations Report 86-4204.

Carrigan, P.H. 1972. "Probability of exceeding capacity of flood-control system at the National Reactor Testing Station, Idaho", U.S. Geological Survey Open-File Report, Waste Disposal and Processing, TID-4500, IDO-22052.

Knutson, C.F., K.A. McCrrmick, J.C. Crocker, M.A. Glenn, and M.L. Fisher. 1.992-expected. "3D RWMC vadose zone model (including FY89-90 basalt characterization results)-informal report", EGG-GEO-9943, E(j\&G Idaho, Inc. Idaho Falls, ID.

Lamke, R.D. 1969. "Stage-discharge relations on the Big Lost River within National Reactor Testing Station, Idaho." U.S. Geological Survey Open File Report, IDO-22050.

Lewis, B.D. and F.J. Goldstein. 1982. "Evaluation of a predictive groundwater solute-transport model at the Idaho National Engineering Laboratory", IDO-22062-USGS.

Rightmire, C.T. and B.D. Lewis. 1987. "Hydrology and geochemistry of the unsaturated zone, Radioactive Waste Management Complex, Idaho National Engineering Laboratory, Idaho", U.S. Geological Survey, Water-Resources Investigations Report 87-4198.

Robertson, J.B. 1974. "Digital modeling of radioactive and chemical waste transport in the Snake River Plain aquifer at the National Reactor Testing Station, Idaho." IDO-22054. Waste Management TID-4500. 


\title{
ATTACHMENT \#3
}

\section{PROPOSAL FOR FLOOD-RELATED STUDIES FOR THE INEL SITE}

\author{
Dennis Horn
}

\section{Work Description}

Although a number of prior studies have addressed various aspects of the potential flood hazards at INEL, there has apparently been no attempt to date to integrate these past studies into an updated comprehensive site-wide flood hazard summary. This proposed research will undertake this effort by performing the following sequence of tasks:

1. A thorough review of all available prior studies and data bases related to flood hydrology and hydraulics will be performed, with a goal of identifying needs for further analyses and data collection. This review will include, at a minimum, the following material:

a) USGS streamflow data (both peak flow and daily flow values) at gages along the Big Lost River.

b) Prior studies related to flood frequency definition for the Big Lost River.

c) Prior studies related to potential impacts from upstream dam failure.

d) Hydrologic and hydraulic studies related to the design of the INEL flood storage basins.

e) Current studies of flood hazards at off-river sites within the INEL boundaries.

f) Channel seepage and groundwater recharge studies, pertinent to reduction in flood volume as flows move towards the playas.

2. Following this review, updated analyses will be made (using the USGS data) to provide flood frequency curves at several locations along the Big Lost River. These analyses will use current on-going research related to channel seepage losses to modify the peak flow data measured upstream from the site boundary.

3. Since the flood hazards at INEL may be more critically related to flood volume, rather than peak flows, additional analyses will be performed to develop flow duration-volume-frequency curves at selected 
sites. Again, these analyses will reflect channel seepage losses downstream from the long-term USGS gaging stations.

4. Based on the foregoing analyses, and the design studies for the flood spreading basins, the adequacy of these basins for reducing on-site flood hazards will be evaluated.

5. Because of the flat terrain at the site, and the lack of detailed topographic data and surveyed floodplain cross-sections, it may be impossible to accurately develop flood profiles or maps of flood hazard area boundaries. This study will therefore conclude with recommendations for whatever additional topographic or survey data may be necessary to clearly define the flood hazards at the site, along with an approximate cost estimate to obtain these data.

All analyses, including a summary of the data used, and a complete bibliography of other flood studies at INEL will be compiled in a Final Report to be submitted at the conclusion of the project. Since the work will be conducted by a graduate student, under the direction of the Principle Investigator, this Final Report will also serve to satisfy the student's thesis requirements for a M.S. in Civil Engineering degree.

\section{Work Schedule}

All tasks will be performed during a 12-month period, with the Final Report submitted prior to the end of the 12th month. 
Proposed Budget

Salaries

$$
\begin{array}{cc}
\text { Faculty - 10\% effect, academic year } & \$ 4,600 \\
\text { 4 weeks, summer 1992 } & 4,700 \\
\text { Graduate Student - Research Assistantship } & 7,200 \\
\text { (two semesters) } & \$ 16,500
\end{array}
$$

Fringe Benefits

Faculty@ 24.5\%

Graduate Student @1\%

$\$ 2,350$

Travel, per diem

$\$ 1,000$

Operational Expenses

$\$ 450$

(computer, supplies, phone, etc.)

Subtotal

$\$ 20,300$

University Overhead @ 20\%

$\$ 4,060$

TOTAL

$\$ 24,360$ 


\section{Recommendations for Data Analysis and Modeling Efforts}

1. Introduction

The INEL's effort on numerical modeling of the transport process in the unsaturated zone is extensive. The activities include code qualification, acquisition, modification, development, verification, applications to specific sites, and quality assurance. The most prominent computer codes in use at INEL include:

FLASH in conjunction with FLAME (Baca, 1992, in preparation)

FLOWMC (Nguyen, Magnuson, and Baca, 1992, in preparation)

UNSAT-H version 2.0 (Fayer and Jones, 1990, Baca et al. 1990)

PORFLOW--3 (Runchal and Sagar, 1989)

TRACR3D (Travis 1984)

Another code named VS2D (Lappala 1987 and Healy 1990)) of the US Geological Survey is also of interest.

We have reviewed the program documentation for PORFLOW-3, TRACR3D, VS2D, and UNSAT-H(Baca and Magnuson 1990) for the purpose of gaining familiarity with general data requirement and modeling methodology. During the second year of the research, we plan to conduct numerical simulations using VS2D and UNSAT-H to achieve the objectives listed below. 


\section{Objectives of the Second Year}

The objectives are:

(1) to be able to establish the data sets from available site data required for simulating specific problems such as the extent of penetration and travel time at particular sites. In doing so, we hope to quantify the spatial variability and uncertainty of the variables involved.

(2) to quantify the most likely main process involved for specific problems.

(3) to rank the input variables according to the extent of influence to the model results.

(4) to be able to draw some probabilistic and quantitative conclusions on the transport process, given the variability and uncertainty of the data.

3. Planned Activities

\subsection{Acquiring Models}

As a first step, we will acquire public domain models that can be run on a high-end PC, namely, VS2D, and UNSAT-H. We have already obtained a version of VS2D from the USGS. UNSAT-H Version 2.0 operable on a VAX mini-computer is available from the Pacific Northwest Laboratories. INEL generalized UNSAT-H Version 2.0 and made it operable on an IBM PC. We would like to avoid code conversions and desire to obtain a copy of the generalized UNSAT-H Version 2.0 from INEL, if possible. INEL's codes FLOWMC, FLASH and FLAME are operable on a PC also. However, these codes do not seem to be in the public domain.

We plan to conduct simulations using VS2D and UNSAT-H Version 2.0. Depending on the availability of the PC version of the other codes, we may explore them also. However, our main focus will be on VS2D and UNSAT-H. 


\subsection{Data Analysis and Data File Preparation}

We will construct representative data files from available data and follow standard assumptions. To facilitate this process, we would like to obtain some data files used by INEL in its previous simulation efforts. After the input variables are identified for each code, we will study the literature to obtain their range of variability, if possible. We also will investigate correlation between input variables.

\subsection{Sensitivity Studies}

Systematic parameter studies will be carried out using VS2D and UNSAT-H for one or two specific problems.

\subsection{Addressing variability and uncertainty}

To accommodate uncertainties in the data, the Monte Carlo method was used at INEL (Baca et al. 1992). we plan to use a much less-computer intensive method proposed by Harr 1989. This method does not require probability distribution functions for the input variables which can be correlated random variables. Potentially, assessing the data uncertainty by the Harr's method provides a check to the results by the Monta Carlo method, and indicates the possibility of using less data to accomplish the same objective.

\section{References}

Baca, R. G., 1992 (in preparation), "A finite Element Computer Code for Variably-Saturated Flow in Fractured Media," EG\&G Idaho, Inc. 
Baca, R. C., Magnuson, S. O., Nguyen, H. D., and Martian. P., 1992, "A Modeling Study of Water Flow in the Vadose Zone Beneath the Radioactive Waste Management Complex." EG\&G Idaho, Inc. EGG-GEO-10068.

Baca, R. G., and Magnuson, S. O., "Independent Verification and Benchmark Testing of the UNSAT-H Computer Code, Version 2.0," EG\&G Idaho, Inc. EGG-BEG-8811.

Fayer, M. J., and Jones, T. L., 1990, "UNSAT-H Version 2.0: Unsaturated Soil Water and Heat Flow Model," Pacific Northwest Laboratory, PNL-6779.

Harr, M. E., 1989, "Probabilistic Estimates for Multivariate Analyses," Applied Mathematics Modeling, Vol. 13, pp. 313-318.

Healy, R. W., 1990, "Simulation of Solute Transport in Variably Saturated Porous Media with Supplemental Information on Modifications to the U. S. Geological Survey's Computer Program VS2D," US Geological Survey, Water Resources Investigations Report 90-4025.

Lappala, E. G., Healy, R. W., and Weeks, E. P., 1987, "Documentation of Computer VS2D to Solve the Equations of Fluid Flow in Variably Saturated Porous Media," US Geological Survey, Water-Resources Report 83-4099.

Nguyen, H. D., Magnuson, S. O., and Baca, R. G., 1992 (in preparation), "Probabilistic Model for Flow and Transport in Porous Media," EG\&G Idaho, Inc.

Runchal, A. K., and Sagar, B., 1989, "PORFLOW-3: A Mathematical Model for Fluid Flow, Heat, and Mass Transport in Variably Saturated Geologic Media," Westinghouse Hanford Company, WHC-EP--0041, DE89 013977.

Travis, B. J., 1984, "TRACR3D: A Model of Flow and Transport in Porous/Fractured Media," Los Alamos National Laboratory, LA-9667-MS, UC-32 and UC-70. 

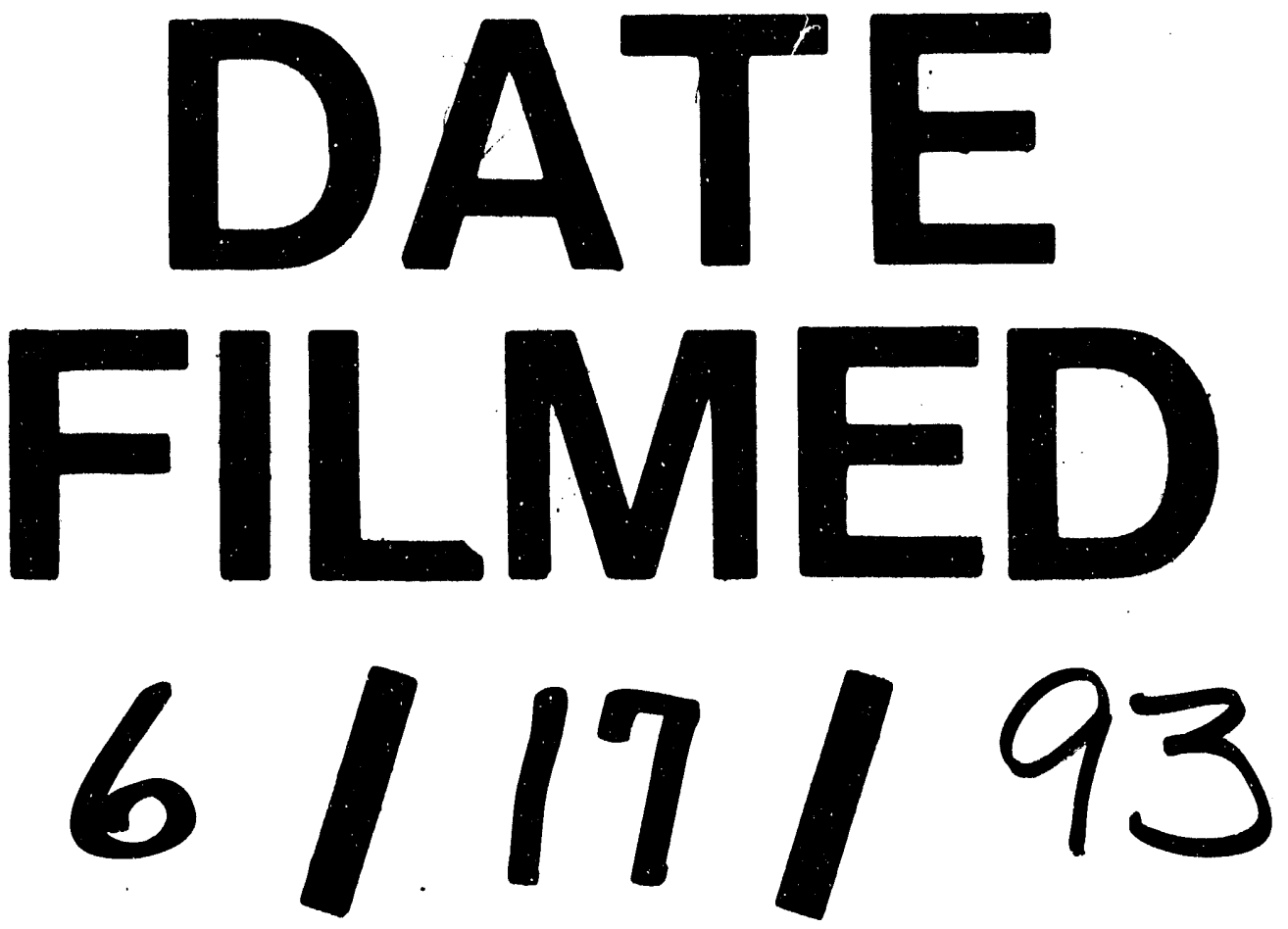
